American Journal of Immunology 5 (3): 65-83, 2009

ISSN 1553-619X

(C) 2009 Science Publications

\title{
Cytokines as Adjuvants for Vaccine and Cellular Therapies for Cancer
}

\author{
${ }^{1}$ Christian M. Capitini, ${ }^{1,2}$ Terry J. Fry and ${ }^{1}$ Crystal L. Mackall \\ ${ }^{1}$ Immunology Section, Pediatric Oncology Branch, Center for Cancer Research, \\ National Cancer Institute, National Institutes of Health, Bethesda, Maryland 20892 \\ ${ }^{2}$ Center for Cancer and Blood Disorders, Children's National Medical Center, \\ Washington, DC 20010
}

\begin{abstract}
Problem statement: The development of a potent vaccine that can help treat tumors resistant to conventional cytotoxic therapies remains elusive. While part of the problem may be that trials have focused on patients with bulky residual disease, the desire to maximize responses to the vaccine remains. Approach: The gamma $(\gamma)$ family of cytokines offered a unique opportunity to support the expansion and effectors potential of vaccine-responding T-cells, as well as stimulate other effectors, such as Natural Killer (NK) cells, to become activated. Results: Combining vaccines with cytokines seems logical but can bring unwanted toxicity, as had been observed with interleukin (IL)-2. In addition, the nonspecific activation or expansion of unwanted cell subsets, such as regulatory T-cells, can contribute to global immunosuppression and limit vaccine responses. The development of IL-7 and IL21 for the clinic offered the promise of enhancing anti-tumor responses but with far less systemic toxicity and no expansion of regulatory T cells. Preclinical studies demonstrated that IL-15 could also improve Tcell and especially NK-cell, responses as well. Conclusion/Recommendations: Future study should expand the use of vaccines with IL-7, IL-21 and hopefully IL-15 in high-risk patients and consider treatment while in a state of minimal residual disease to maximize benefit. Identifying tumors that can signal through gamma(c) cytokines will also be essential so that induction of relapse will be avoided.
\end{abstract}

Key words: Interleukin 2 , interleukin 7 , interleukin 15 , interleukin 21 , tumor vaccines

\section{INTRODUCTION}

Despite the success of multimodality therapy for cancer including chemotherapeutic agents, radiation and surgery, relapse still occurs in a large percentage of patients. Immune effectors cells represent a powerful tool for eliminating residual tumor cells. The potency of Donor Lymphocyte Infusions (DLI) in treating chronic myelogenous leukemia following Hematopoietic Stem Cell Transplant (HSCT) is a striking example of the potential of cancer immunotherapy. Clinical responses to adoptive cell therapies administered in the autologous setting further illustrate the promise of cancer immunotherapy. The development of vaccines designed to elicit adaptive immune responses, mainly from T-cells, has occurred in parallel with adoptive cell therapy, but it is evident based on the clinical data generated with vaccines thus far that approaches to increase potency will be necessary. Indeed, the great appeal of this approach is the potential to generate immunotherapies that are antigen-specific, with a particular focus on tumor-associated antigens. One of the main drawbacks to this approach, however, is that tumor antigens represent self-proteins, which can induce tolerance in the host. Thus, vaccines have been examined in combination with other immunotherapies as a means of generating a potent $\mathrm{T}$-cell response against tumor antigens while overcoming the barriers of tolerance.

Vaccines are being pursued for multiple types of cancers and are being designed using multiple approaches to enhance immunogenicity. Administration of whole cancer cells, purified peptides, or DNA vaccines have been given alone, or in combination, with professional Antigen Presenting Cells (APCs) to elicit immunogenic responses. Combinations of different types of immunotherapy with traditional modalities like chemotherapy, radiation and surgery, have been tested in clinical trials with some promise. Cytokines delivered with vaccines as adjuvants aim to improve antitumor immunity by increasing the proliferation of effectors cells and also improving their cytotoxicity or cytokine production ${ }^{[1]}$. It has been demonstrated in preclinical models that concurrent administration of cytokines with a vaccine has the potential to enhance

Corresponding Author: Christian M. Capitini, Building 10, Room 1W-5832, MSC 1104, 10 Center Drive Bethesda, MD 20892 Ph: 301-451-7033 Fax: 301-451-7052 
immune reactivity through the recruitment of $T$ cells and APCs to lymphoid organs, as well as by activation of T-cells and Natural Killer (NK) cells directly. In this review, we will discuss clinically relevant cytokines that have been coupled with a vaccine or cellular therapy in preclinical models and in some cases clinical trials, to generate antitumor immune responses, with a focus on the so-called gamma(c) family of cytokines. These cytokines (Interleukin 2, Interleukin 7, Interleukin 15 and Interleukin 21) all utilize the common cytokine gamma chain for signaling and have potent effects on T-cells and NK cells, the major effectors in the anti-tumor immune response.

\section{Interleukin 2:}

Background: The first cytokine administered in a vaccine trial against cancer was interleukin 2 (IL-2). IL2 is produced mainly by $\mathrm{T}$ helper cells, acts on a variety of immune cells across the innate and adaptive immune system and is known to play an important role in the initiation and maintenance of antigen-specific immune responses (Fig. 1). The biology and signaling pathways of IL-2 have been reviewed extensively ${ }^{[1,2]}$. Because of the broad effects of IL-2 on a variety of immune cells, the specific mechanisms by which IL-2 influences the immune system to induce tumor regression are not completely understood.

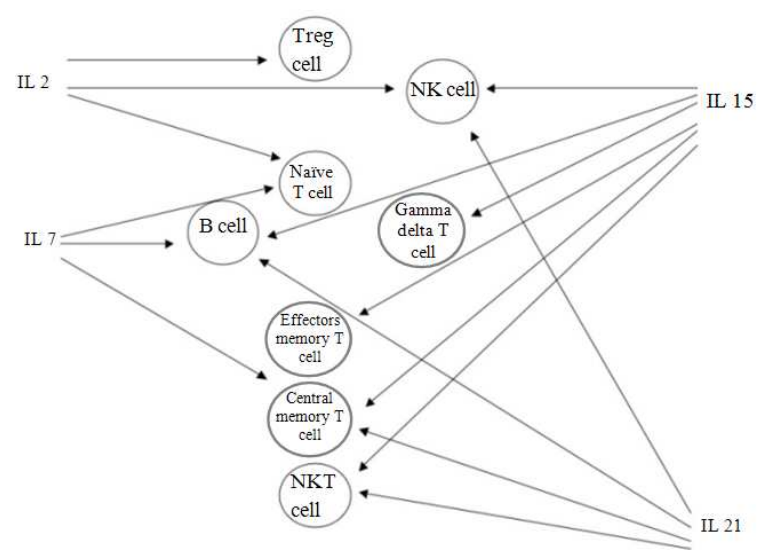

Fig. 1: Target lymphocyte populations of gamma(c) cytokines. While there is considerable overlap of cytokine activity on lymphocytes, effects can be stimulatory or inhibitory depending on the cytokine. IL-21 only increases proliferation of T cells stimulated with anti-CD3 or antigen, but can augment responses to other gamma(c) cytokines. IL-7 acts on developing B cells but not mature cells of this lineage. IL: Interleukin, NK: Natural Killer, NKT: Natural Killer-T cell, Treg: Regulatory T cell
A variety of preclinical models demonstrated potential therapeutic benefit of combining IL-2 with vaccines, leading to the study of IL-2 in clinical trials. The antitumor effect of IL-2 is believed to be mediated by lymphocyte expansion and augmentation of effector cell function ${ }^{[2]}$. However, while IL-2 enhances the activity of both NK cells and T-cells, it can also expand regulatory T-cells (Tregs), which contribute to tumorassociated immunosuppression ${ }^{[3]}$. The Food and Drug Administration approved IL-2 as a single agent for use in patients with metastatic Renal-Cell Carcinoma (RCC) (1992) and metastatic melanoma (1998). IL-2 has also shown efficacy as an adjuvant for infectious vaccine therapy. As will be outlined below, objective tumor responses have been observed in clinical trials combining cancer vaccines with IL-2. An informative commentary on the history of IL-2 treatment for melanoma is available ${ }^{[4]}$. This review will explore IL-2 as a prototypic cytokine that acts as an adjuvant to vaccine therapy by examining the relevant clinical trials in melanoma, where there is the most clinical experience in adults, as well as in pediatric solid tumors. A review of the experience with IL-2 and vaccines in RCC is discussed elsewhere ${ }^{[5]}$. Given the diversity of clinical trial designs using IL-2 as an adjuvant, we will also discuss dosing, timing of administration and reported objective response rates as potential factors that may impact efficacy.

Clinical Trials with Vaccines and IL-2 in Melanoma: When examining the literature on IL-2 given with therapeutic vaccines for melanoma, studies vary by the type of vaccine administered, IL-2 dose, timing of IL-2 administration in relation to the vaccine and length of therapy (Table 1). The earliest data for systemic IL-2 following vaccination was reported by Rosenberg et al. ${ }^{[6]}$ in 1998, who used high-dose IL-2 immediately following vaccination with a modified gp100 (a relevant melanoma tumor-associated antigen) peptide vaccine in 31 patients with melanoma. A $42 \%$ objective response rate was reported, while the vaccine alone had a $5 \%$ response rate ${ }^{[6]}$. This initial observation led to the development of further trials with more advanced vaccines, but served as a "proof of principle" study that vaccines combined with a cytokine can improve objective tumor response rates over vaccines alone. Another report by this group with a different peptide vaccine and IL-2 demonstrated a $38 \%$ objective response rate, although it was not documented whether they were Partial Remissions (PRs) or Complete Remissions (CRs), nor how long responses were maintained $^{[7]}$. However, other trials in melanoma incorporating peptide vaccines with IL-2 have shown either response rates similar to that seen with IL-2 alone (about $15-25 \%$ ), or no responses at all ${ }^{[8,9]}$. One trial did not report a specific response rate ${ }^{[10]}$. 
Am. J. Immunol., 5 (3): 65-83, 2009

Table 1: Analysis of melanoma trials where patients received both IL-2 and a vaccine

\begin{tabular}{|c|c|c|c|c|}
\hline Vaccine & IL-2 Dose/route & Timing/length of IL-2 therapy & Objective response rate & References \\
\hline \multicolumn{5}{|l|}{ Peptide (Day+0) } \\
\hline g209-2M & $720,000 \mathrm{I} \mathrm{U} \mathrm{kg}^{-1} \mathrm{IV}$ & $\begin{array}{l}\text { Start day }+1 \text { or }+5 \text { until grade } 3-4 \\
\text { irreversible toxicity (tolerance) }\end{array}$ & $42 \%$ & [6] \\
\hline g209-2M & $720,000 \mathrm{IU} \mathrm{kg}^{-1} \mathrm{IV}$ & Same as above (6-10 doses) & $38 \%$ & [7] \\
\hline Tyrosinase + & $3,600,000 \mathrm{IU} \mathrm{m}^{-2} \mathrm{SC}$ & Group 1: Start day+7 & Not reported & [10] \\
\hline gp100+ & & Group 2: Start day +28 . & $0 \%$ & [8] \\
\hline tetanus helper & & Daily for 6 weeks in both groups & & \\
\hline g209-2M & $5,000,000 \mathrm{IU} \mathrm{m}^{-2} \mathrm{SC}$ & Days +0 to +4 and days +7 to +12 & $16 \%$ & [9] \\
\hline \multirow[t]{4}{*}{ g209-2M } & $600,000 \mathrm{IU} \mathrm{kg}^{-1} \mathrm{IV}$ & $\begin{array}{l}\text { Start day }+1 \text { for } 5 \text { days on: repeated } \\
\text { every } 21 \text { days }\end{array}$ & & \\
\hline & & Weeks 1 and 3 for trial one & & \\
\hline & & Weeks 7 and 9 for trial two & & \\
\hline & & Weeks $1,4,7 \& 10$ for trial three & & \\
\hline DC or PBMCs & $720,000 \mathrm{IU} \mathrm{kg}^{-1} \mathrm{IV}$ & Start day +0 for 3 days & $0 \%$ & {$[12]$} \\
\hline \multicolumn{5}{|l|}{ DC + MART-1 + g209-2M } \\
\hline $\mathrm{DC}+$ tumor lysate & 700,000 IU SC & Start day $+0,3$ times/week & $0 \%$ & [14] \\
\hline Tumor/DC hybrid cell & $3,000,000 \mathrm{IU} \mathrm{SC}$ & Start day +0 for 6 days & $0 \%$ & [15] \\
\hline $\mathrm{DC}+$ tumor lysate & $2,400,000 \mathrm{IU} \mathrm{m}^{-2} \mathrm{SC}$ & Start day +1 for 3 days & $0 \%$ & [16] \\
\hline Tumor/DC hybrid cell & $3,000,000 \mathrm{IU} \mathrm{m}^{-2}$ & Start day +1 for 5 days & $10 \%$ & [17] \\
\hline $\mathrm{PBMC}+\mathrm{g} 209-2 \mathrm{M}$ & $720,000 \mathrm{IU} \mathrm{kg}^{-1} \mathrm{IV}$ & Start day +0 until tolerance ( $4-11$ doses) & $0 \%$ & [18] \\
\hline \multirow[t]{2}{*}{$\mathrm{DC}+$ tumor lysate } & $3,000,000 \mathrm{IU} \mathrm{SC}$ or & Low: Start Day+0 for 4 days & $0 \%$ & [13] \\
\hline & $360,000 \mathrm{IU} \mathrm{kg}^{-1} \mathrm{IV}$ & High: Start Day+0 for 9 doses & & \\
\hline $\mathrm{DC}+$ tumor lysate or & $1,000,000 \mathrm{IU} \mathrm{m}^{-2} \mathrm{SC}$ & Start day +1 for $5-14$ days & $0 \%$ (lysate) & [11] \\
\hline DC + peptide cocktail & & & $22 \%$ (peptides) & \\
\hline \multicolumn{5}{|l|}{ Other } \\
\hline $\begin{array}{l}\text { Adenovirus + MART-1 or } \\
\text { Adenovirus + gp100 }\end{array}$ & $720,000 \mathrm{IU} \mathrm{kg}^{-1} \mathrm{IV}$ & Start day +1 until tolerance & $16 \%$ & [20] \\
\hline Fowlpox virus $+\mathrm{g} 209-2 \mathrm{M}$ & $720,000 \mathrm{IU} \mathrm{kg}^{-1} \mathrm{IV}$ & $\begin{array}{l}\text { Start day+0 up to } 12 \text { doses every } \\
4 \text { weeks }\end{array}$ & $50 \%$ & [21] \\
\hline SRL172 (Mycobacterium) & $6,000,000$ IU SC & Start day+0 for 3 days & $19 \%$ & [23] \\
\hline $\mathrm{DNP}+\mathrm{BCG}+$ tumor & $\begin{array}{l}3,000,000 \mathrm{IU} \mathrm{SC} \\
\text { or } 720,000 \mathrm{IU} \mathrm{kg}^{-1} \mathrm{IV}\end{array}$ & $\begin{array}{l}\text { Low: Start day+0 for } 5 \text { days } \\
\text { every } 14-21 \text { days }\end{array}$ & $42 \%$ & [19] \\
\hline & & $\begin{array}{l}\text { High: Start day+0 for } 2 \text { weeks, } \\
1 \text { week rest, then repeat once }\end{array}$ & & \\
\hline $\begin{array}{l}\text { Tumor plasma membrane } \\
\text { on silica beads }\end{array}$ & $1,750,000 \mathrm{IU} \mathrm{m}^{-2} \mathrm{SC}$ & Start day +5 from vaccine for 1 week & $0 \%$ & [22] \\
\hline
\end{tabular}

IV: Intravenous; SC: Subcutaneous

While it could be argued that peptides are inefficient as vaccines since they need to be expressed by an APC and presented with costimulatory signals to get a proper effector response, studies have also examined IL-2 given with a dendritic cell (DC) vaccine. In these studies, the vaccine is potentially capable of presenting a melanoma antigen directly and IL-2 could facilitate expansion of any vaccine-responding cells. Unfortunately the response rates in these trials were quite poor $^{[11-17]}$. One group even adopted a similar approach using Peripheral Blood Mononuclear Cells (PBMC), instead of DCs, to patients pretreated with other vaccines and saw no objective clinical responses $^{[18]}$.

In contrast to using APCs, one report using a dinitrophenyl-modified autologous melanoma cell vaccine as either a primary treatment or as an adjuvant showed $42 \%$ objective tumor regression (2CR, 8PR) following combination with IL-2, lasting for a median duration of 6 months (range 3-50 months) ${ }^{[19]}$. Viruses have also been explored as a means of presenting over expressed melanoma antigens and whereas adenovirus vaccines yielded no responses ${ }^{[20]}$, another report using a recombinant fowlpox virus encoding a minigene construct encoding a single, modified melanoma epitope yielded a 50\% response rate (3CR, 3PR) when given with $\mathrm{IL}-2^{[21]}$. Regarding nonviral approaches, using melanoma plasma membranes on silica beads showed no responses ${ }^{[22]}$ and giving only heat-killed Mycobacterium without any tumor antigens was no better than giving IL-2 alone ${ }^{[23]}$. Thus, no controlled randomized vaccine trial \pm IL-2 have reported that IL2 improves responses to a tumor vaccine and in a multitude of non-controlled trials response rates to tumor vaccines remain low, whether or not IL-2 is coadministered. Moreover, a meta-analysis of the vaccine trials at the National Cancer Institute (NCI) demonstrated that melanoma vaccines in general, 
when given with IL-2, do no better than giving IL-2 alone ${ }^{[24]}$.

Clinical trials with pediatric cancers: The clinical experience in pediatrics with IL-2 and vaccines has been more limited, with neuroblastoma the most extensively studied. Investigators have used IL-2secreting autologous neuroblastoma cell lines as vaccines and a transgenic chemokine-cytokine (lymphotactin-IL-2) vaccine generated in autologous and allogeneic neuroblastoma cell lines ${ }^{[25-27]}$. Except for a few patients with PRs or CRs, all of the response rates were disappointing. Importantly, very recent research has demonstrated that IL-2 combined with GM-CSF and a monoclonal antibody against GD2-expressing neuroblastomas can lead to enhanced event-free and overall survival in a phase III trial ${ }^{[28]}$. This data demonstrates the efficacy of IL-2 as an adjuvant to monoclonal antibody therapy rather than as an adjuvant for T-cell active vaccines and illustrates the potential effectiveness of cytokines in cancer immunotherapy in the context of a large, well-designed clinical trial conducted at multiple centers through a cooperative oncology group.

In addition to neuroblastoma, Dagher et al. ${ }^{[29]}$ reported in 2002 no clinical benefit of a PBMC vaccine pulsed with tumor peptides given with IL-2 in children with recurrent Ewing sarcoma and alveolar rhabdomyosarcoma. A follow up study by Mackall et $a l^{[30]}$ in the same patient populations gave autologous T-cells and DCs pulsed with peptides derived from tumor-specific translocation breakpoints and was reported in 2008 using different doses of IL-2 administered to three cohorts. Immune responses to the translocation breakpoint peptides occurred in only $39 \%$ of patients. There was a $43 \% 5$ year overall survival for patients initiating immunotherapy, which is higher than would be predicted for patients with this level of highrisk disease, although no differences were seen in cohorts that received or did not receive IL-2. Additional data generated from this trial definitively demonstrated that in vivo administration of IL-2 results in expansion of Tregs. Zhang et al ${ }^{[3]}$ showed that $\mathrm{CD} 4^{+} \mathrm{CD} 25^{+}$Tregs underwent homeostatic peripheral expansion during immune reconstitution, that IL-2 therapy expanded this subset and that this expansion was further augmented by lymphopenia.

In a leukemia trial that included 7 children with high-risk acute myeloid leukemia or Acute Lymphoblastic Leukemia (ALL) in cytologic remission, patients received up to 6 subcutaneous injections of a tumor vaccine consisting of leukemic blasts admixed with skin fibroblasts transduced with adenoviral vectors encoding IL-2 and CD40 ligand. Eight patients remained disease-free for a range of 27-62 months after treatment, with a 5 year overall survival of $90 \%{ }^{[31]}$. Thus, IL-2 therapy is well tolerated in pediatric patients despite being heavily pretreated for their primary disease and may enhance the cytotoxicity of both T-cell and non- $\mathrm{T}$ cell subsets, but Treg expansion remains an issue.

Limitations of IL-2: There remains considerable debate about the dosing, schedule and timing of IL-2 administration in relation to vaccination. In general, high dose IL-2 appears to be associated with better clinical responses in melanoma (Table 1), although there is minimal data directly comparing IL-2 dosing. What is well documented is that higher doses of IL-2 cause appreciable toxicity, namely capillary leak ${ }^{[2]}$. In addition, elevation of IL- 6 has been associated with IL2-induced mental depression ${ }^{[32]}$ and IL-2 therapy can result in autoimmune toxicities, including vitiligo, Type I diabetes or autoimmune thyroiditis ${ }^{[33]}$, perhaps indicative of the potential for these cytokines to induce tumor responses against self-antigens. IL-10 production may be a direct result of Treg stimulation and may hamper antitumor effects. In addition, IL-2 mediates activation-induced cell death, which could also hamper $\mathrm{T}$-cell responses to a vaccine ${ }^{[2]}$. Lastly, there is some concern that IL-2 may signal tumors themselves ${ }^{[34-42]}$, particularly lymphoid-derived cancers and some adult carcinomas (Table 2).

In summary, most vaccines tested with IL-2 do not do better than IL-2 alone, although there are many factors that can affect outcome, including the type of vaccine, dose and schedule of IL-2 and antigen targeted. Importantly, the relative expansion of Tregs may also be hampering responses. Future research will need to address limiting expansion of this subset. In addition, almost all of the patients treated in these trials had measurable and often bulky, tumors at the time of enrollment. It is possible that vaccines and IL-2 may work better in a Minimal Residual Disease (MRD) setting and future work should focus on using these two modalities as a means to minimize relapse. With regards to scheduling and timing of IL-2, in most clinical trials, IL-2 is usually given at the same time or following vaccination (Table 1). IL-2 might be more effective if given before vaccine administration, so the milieu will promote proinflammatory immune responses $^{[10]}$, or if IL-2 is delayed until after the T-cell contraction phase ${ }^{[43]}$. Overall, the relatively low rate of clinical responses to vaccines with IL-2, regardless of dosing or schedule, indicates that IL-2 may not be optimal as an adjuvant. 
Am. J. Immunol., 5 (3): 65-83, 2009

Table 2: Malignancies implicated to utilize gamma(c) cytokines

\begin{tabular}{|c|c|c|c|}
\hline Cytokine & Malignancy & Evidence & References \\
\hline \multirow[t]{11}{*}{ IL-2 } & Hodgkin disease & $\mathrm{IL}^{-} 2 \mathrm{R}^{+}$or $\mathrm{CD} 25^{+}$by IHC & {$[34,35]$} \\
\hline & B- and T-cell lymphomas & $\mathrm{IL}^{-} 2^{+}$or $\mathrm{IL}-2 \mathrm{R}^{+}$or $\mathrm{CD} 25^{+}$by IHC & {$[34-37,42]$} \\
\hline & & IL-2mRNA in CD $25^{+}$cells & \\
\hline & & IL-2 can signal and promotes proliferation & \\
\hline & T-cell leukemias & Aberrant expression CD25mRNA & [38] \\
\hline & B-cell CLL & $\mathrm{CD}^{2} 5^{+}$and $\mathrm{CD} 122^{+}$by antibody and mRNA analysis & [39] \\
\hline & & IL-2 induces proliferation of $\mathrm{CD} 25^{+}$cells & \\
\hline & Head and neck carcinoma & Surface IL- $2^{+}$and $\mathrm{CD} 122^{+}$and intracellular IL- $2^{+}$by flow cytometry & {$[40,41]$} \\
\hline & & Anti-CD25 treatment induces G1 arrest and induces apoptosis in vitro & \\
\hline & Gastric carcinoma & Surface IL-2 $2^{+}$and $\mathrm{CD} 122^{+}$and intracellular IL- $2^{+}$by flow cytometry & [40] \\
\hline & Squamous cell lung carcinoma & $\mathrm{IL}-2^{+}$and $\mathrm{CD} 25^{+}$by IHC & [37] \\
\hline \multirow[t]{11}{*}{ IL-7 } & Acute B-cell leukemia & IL-7R mRNA ${ }^{+}$IL-7R protein ${ }^{+}$and shows in vitro kinase activity & {$[58,60,61,64]$} \\
\hline & & Growth inhibition by rapamycin reversed by IL-7 & \\
\hline & & CD127 is alternatively spliced & \\
\hline & Acute T-cell leukemia & Notch1 binds to IL-7R promoter, regulates & \\
\hline & & IL-7R transcription and CD127 expression & \\
\hline & Hodgkin disease & IL-7R ${ }^{+}$by flow cytometry and IHC & \\
\hline & & IL-7 stimulates growth in colony assays & \\
\hline & & IL-7 prevents apoptosis in serum-free assays & [62] \\
\hline & Lung carcinoma & IL-7R mRNA $^{+}, \mathrm{IL}^{-}-7 \mathrm{R}$ protein ${ }^{+}$and in vitro kinase activity & \\
\hline & & IL-7 induces VEGF-D and promotes lymphangiogenesis & {$[58,59]$} \\
\hline & Brain tumors & IL-7R is alternatively spliced & [64] \\
\hline \multirow[t]{9}{*}{ IL-15 } & Large granular leukemia & IL-15 stimulates proliferation & {$[105,106]$} \\
\hline & & IL-15 induces all known signaling deregulations & \\
\hline & CLL & $\begin{array}{l}\text { IL-15 causes receptor signaling, proliferation } \\
\text { and prevents apoptosis }\end{array}$ & [107] \\
\hline & & $\begin{array}{l}\text { Cells stimulated with CD } 40 \text { exhibit increased } \\
\text { expression of IL-15R }\end{array}$ & \\
\hline & Pediatric ALL & High IL-15 expression correlates with CNS involvement & [111] \\
\hline & Cutaneous T cell lymphoma & IL-15 can signal and promote proliferation & [42] \\
\hline & Renal cell carcinoma & IL- $15 R^{+}$by flow cytometry and RT-PCR & [109] \\
\hline & & IL- 15 can signal IL-15R & \\
\hline & Head and neck carcinoma & IL-15Ra ${ }^{+}$by RIA & {$[108]$} \\
\hline \multirow[t]{9}{*}{ IL-21 } & $\mathrm{T}$ cell leukemia & IL-21R ${ }^{+}$by flow cytometry and RT-PCR & \\
\hline & & IL-21 induces signaling and proliferation & [140] \\
\hline & Hodgkin disease & IL- $21^{+}$by flow cytometry, RT-PCR and IHC & \\
\hline & & IL- $21 R^{+}$by flow cytometry & \\
\hline & & IL-21 signals STAT5 to cause proliferation & {$[156,157]$} \\
\hline & & IL-21 protects cells from apoptosis & \\
\hline & B- and T-cell lymphomas & IL- $21 \mathrm{R}^{+}$by flow cytometry & {$[140]$} \\
\hline & & IL-21 causes proliferation & \\
\hline & Multiple myeloma & $\begin{array}{l}\text { IL-21 signals and is a growth factor via an } \\
\text { IGF-1 autocrine loop }\end{array}$ & [158] \\
\hline
\end{tabular}

IHC: Immunohistochemistry, CNS: Central Nervous System, RT-PCR: Reverse Transcriptase-Polymerase Chain Reaction, RIA: Radioimmunoassay

\section{Interleukin-7:}

Background: IL-7 is produced by a variety of cell types and tissues, but not by lymphocytes themselves and serum IL-7 levels are inversely correlated with lymphocyte counts. IL-7 is involved in the maintenance and survival of alpha-beta T cells, the development of B cells and gamma-delta $\mathrm{T}$ cells and may play a role in the biology of DCs and monocytes ${ }^{[44,45]}$ (Fig. 1). IL-7 does not appear to support NK cells. Thus, IL-7 plays a critical role in lymphocyte homeostasis as indicated by markedly diminished lymphocyte counts in IL-7 and IL-7 receptor gene deleted mice and the severe combined immunodeficiency associated with IL-7 receptor mutations in humans. An extensive review of
IL-7 biology and signaling can be found elsewhere ${ }^{[44,46,47]}$, but this review will focus on potential clinical utility of recombinant human (rh) IL-7 as an agent for immunorestoration or as adjuvant therapy for vaccines or adoptively transferred T cells. Preliminary data thus far demonstrates that IL-7 therapy enhances immune reconstitution, but without stimulating Treg expansion or inducing capillary leak, as occurs with IL2.

Clinical trials with IL-7: The first rhIL-7 phase I trial reported 12 patients with metastatic cancers. The four tested doses were $3,10,30$ and $60 \mu \mathrm{g} \mathrm{kg}^{-1}$ given subcutaneously every 3 days for a total of eight doses. 
Patients also received the melanoma antigen peptide vaccines gp100 and MART-1 in incomplete Freund's adjuvant subcutaneously. The therapy was well tolerated and no MTD was reached. While no antitumor effects were observed, rhIL-7 was given for limited time combined with a limited number of vaccines, therefore limiting the conclusions that could be drawn regarding its capacity to enhance vaccine responses. Of note, $\mathrm{CD}^{+}$and $\mathrm{CD}^{+}$T-cell subsets increased in this trial in a dose-dependent manner. However, there was a relative decrease in regulatory $\mathrm{T}$ cells, making this cytokine distinct from IL-2. There was also an increase in B cell precursors in the bone marrow of some patients, but no changes in B cell numbers were noted peripherally ${ }^{[48]}$.

The second rhIL-7 phase I trial reported 16 patients with refractory malignancies using the same doses as the first trial, but IL-7 was given every other day for 14 days and no vaccines were administered. The therapy was well tolerated and no MTD was reached. No antitumor effects were observed, however rhIL-7 increased both $\mathrm{CD}^{+}$and $\mathrm{CD}^{+} \mathrm{T}$ cells, including central memory subsets, in a dose-dependent fashion and these increases lasted for weeks after discontinuation of the cytokine. The mechanism of expansion appeared to be augmentation of peripheral cycling with a propensity for cycling of naïve populations. While enhanced thymic output could not be definitively discerned, rhIL7 induced increased $\mathrm{T}$ cell repertoire diversity as measured by spectratyping, presumably due to enhanced cycling of recent thymic emigrants. Notably, Tregs were not increased, making this clearly cytokine distinct from IL-2 ${ }^{[49]}$.

Lastly, a phase I trial using melanoma cells engineered to express IL-7 lead to an increase in melanoma-reactive $\mathrm{T}$ cells in three out of six patients. Minor antitumor responses were observed in two patients $^{[50]}$. While this trial is not the equivalent of giving IL-7 directly, it further demonstrated that IL-7 is well tolerated in vivo and is effective in mediating effector $\mathrm{T}$ cell expansion without associated Tregs.

Potential antitumor applications of IL-7: While IL-7 alone does not seem to eliminate tumors directly, rationale combination with other immunotherapies may be beneficial. In preclinical models, IL-7 therapy potently enhances vaccine-mediated immunity ${ }^{[51,52]}$. Combining intralesional IL-7 with other therapies, such as Radiofrequency Ablation (RFA), induces immune responses to breast tumors, inhibits tumor development and lung metastasis and reduces myeloid-derived suppressor cells ${ }^{[53]}$. Combining IL-7 with local hyperthermia also enhances anti-tumor activity in mice with melanoma ${ }^{[54]}$ and combining IL-7 and lymphocytes results in prolonged survival from colon cancer $^{[55]}$. In a preclinical neuroblastoma xenograft model, combining IL-7 and gamma-delta T cells with an anti-GD2 antibody significantly improved survival $^{[56]}$. Thus in both adult and pediatric solid tumor models, IL-7 has the capability to be an effective adjuvant. Recently, adjuvant IL-7 was shown to improve vaccine mediated survival in a spontaneously occurring murine tumor model via enhanced Th17 differentiation and reduced $\mathrm{T}$ cell-intrinsic inhibitory networks ${ }^{[51]}$.

Finally, IL-7 may have utility after allogeneic HSCT, where it may enhance Graft-Versus-Leukemia (GVL) effects by potentiating alloreactive $\mathrm{T}$ cells ${ }^{[57]}$. Thus, the available preclinical data and limited data from clinical trials would indicate that via multiple mechanisms, IL-7 is a very promising agent to enhance overall immune competence and, potentially, tumor specific immune responses. The absence of Treg expansion and the lack of toxicity observed in this clinic would suggest that IL-7 offers definite advantages over IL-2 as an adjuvant.

Potential limitations of IL-7 therapy: A potential concern regarding IL-7 therapy is that it may signal tumors directly ${ }^{[58-62]}$, promoting growth/survival (Table 2). CD127 expression has been reported on some adult solid tumors ${ }^{[58]}$, but not on pediatric solid tumors, but it is not clear if these tumors have the capacity to signal through IL-7. IL-7 does play a role in either the initiation or maintenance of some leukemias and lymphomas and therefore will need to be used with extreme caution in immunotherapy regimens involving lymphoid malignancies. It could be that malignant tissues alternatively splice IL-7, as shown in neuronal tumors and pediatric ALL ${ }^{[63,64]}$, which suggests that some tumors could generate their own supply of IL-7 for survival or possibly use an isoform as a means of local IL-7 receptor blockade on effector cells. Some neuronal tumors also alternatively splice the IL-7 receptor, suggesting the tumor could modulate their ability to respond to exogenous IL- $7^{[64]}$.

While IL-7 has been shown to enhance GVL responses after allogeneic HSCT, it may also exacerbate Graft-Versus-Host-Disease (GVHD) ${ }^{[65,66]}$. Thus, the use of IL-7 in the allogeneic setting may be most effective in the setting of $T$ cell-depleted grafts ${ }^{[67]}$. IL-7 over expression has been described to create an osteoclastogenic microenvironment within the bone marrow, which promotes the commitment of precursors towards the osteoclast lineage, leading to bone loss ${ }^{[68]}$. Lastly, additional pre-clinical work has shown that IL-7 therapy may generate a suppressive DC that does not 
present antigen effectively ${ }^{[45]}$. Careful selection of tumors along with close monitoring of bone density and the development of autoimmunity may be necessary in future trials. However, the overall experience with IL-7 thus far would indicate that clinical trials with this cytokine in multiple settings, including as a vaccine adjuvant, are warranted.

\section{Interleukin-15:}

Background: IL-15 is constitutively expressed by a variety of cell types and tissues, but in contrast to IL-2, is mainly membrane bound. A thorough review of IL15 biology and receptor physiology has been described elsewhere ${ }^{[1,2,69]}$. IL-15 and IL-2 exhibit similar immune effects and share the IL-2 receptor subunits IL-2Rbeta and IL-2Rgamma(c), but each cytokine has a separate alpha receptor $(\mathrm{Ra})$. One unique feature of IL-15 is the requirement for cross presentation by IL-15Ra in order to induce optimal biologic activity. Unlike most cytokines that function as soluble mediators, IL-15 appears to function primarily as a "cell associated" molecule and therefore is highly dependent upon an available reservoir of IL15Ra ${ }^{+}$cells for optimal biologic activity. It is possible that this feature of IL-15 biology will have important implications for how best to utilize this cytokine as a therapeutic agent ${ }^{[70]}$.

IL-15 is required for the differentiation of NK cells ${ }^{[71]}$ and plays a role in maintaining and expanding $\mathrm{CD}^{+} \mathrm{T}$ cells (particularly memory subsets) ${ }^{[72-74]}$, NK cells $^{[75]}$, NKT cells ${ }^{[76,77]}$, interferon-killer DCs ${ }^{[78,79]}$ and gamma-delta $\mathrm{T}$ cells ${ }^{[80,81]}$. In addition to effects on T cells and NK cells, IL-15 may also sustain B cells ${ }^{[82]}$ and convert polymorphonuclear cells into $\mathrm{APCs}^{[83]}$ (Fig. 1). Finally, there has been a number of reports exploring NK cell-DC cross talk and IL-15 is presented by DCs to NK cells to enhance survival ${ }^{[84,85]}$. Based upon these properties, investigators have incorporated IL-15 with or onto artificial APCs to expand NK cells ${ }^{[86-88]}$. IL-15 has not been tested in clinical trials yet, but is being developed by the NCI for clinical use ${ }^{[2]}$. Thus, exploration of preclinical data is warranted to gain a full understanding of the potential impact in the clinic.

IL-15 and preclinical tumor models: While IL-15 may have direct anti-tumor effects, most studies demonstrate that it acts as an adjuvant to enhance antitumor immunity, as was described with IL-2 and IL-7. IL-15 is superior to IL-2 in lung adenocarcinoma models $^{[89]}$ and can improve immunity against colon cancer ${ }^{[90,91]}$. Moreover, IL-15 treatment increased amphoterin (HMGB1) secretion by colon cancer cells, which was associated with a depletion of tumorassociated macrophages ${ }^{[92]}$. In melanoma, IL-15 can mediate regression of established tumor ${ }^{[93]}$ and may also enhance tumor-resident $\mathrm{CD} 8+\mathrm{T}$ cells rather than attract newly infiltrated $\mathrm{T}$ cells $\mathrm{s}^{[94]}$. When combined with IL-7 or IL-12, it may even be better than the "gold standard" of IL-2 to enhance T cell-mediated killing of melanoma ${ }^{[95,96]}$. NK cells show enhanced killing of Ewing sarcoma cells after IL-15 administration ${ }^{[97]}$. RFA of breast tumors combined with intralesional IL-15 (and IL-7) inhibits tumor development and metastasis $^{[53]}$. IL-15 enhances NK cell cytotoxicity of human glioblastoma cells, which are resistant to freshly isolated NK cells ${ }^{[98]}$. IL-15 also can reverse the unresponsiveness to the antigen WT-1 in prostate cancer lines, leading to restored expansion and gamma interferon production of WT1-specific T cells ${ }^{[99]}$. Thus IL-15 may enhance anti-tumor immune responses to a wide variety of pediatric and adult malignancies.

There have been numerous preclinical studies exploring IL-15 as a vaccine adjuvant. Although the majority has been in infection models, a number of reports of the adjuvant effect of IL-15 have been published. One important observation is that IL-15 can revert tolerant $\mathrm{T}$ cells to become effectors ${ }^{[100]}$. Adjuvant use of IL-15 can enhance vaccine responses to both dominant and subdominant, tumor antigens ${ }^{[101]}$. Recently, IL-15 administered after a gene-modified vaccine resulted in enhanced anti-tumor activity in a murine melanoma model ${ }^{[96]}$. After allogeneic HSCT, IL15 seems to upregulate NK cell activating receptors ${ }^{[102]}$ and administration of IL-15 with IL-2 enhanced NKDLI-mediated GVL ${ }^{[103]}$. Importantly, although IL-15 is thought to act primarily on mature $\mathrm{T}$ cells, it may prove to be beneficial after T cell-depleted $\mathrm{HSCT}^{[104]}$. Based on the available pre-clinical data, IL-15 would appear to be well suited as an adjuvant to cancer vaccines.

Potential limitations of IL-15 therapy: The main limitation is that IL-15 is not yet readily available. Despite the fact IL-15 was cloned in 1994, rhIL-15 remains under development by the $\mathrm{NCI}^{[2]}$. Some caution should be expressed with IL-15 administration in certain tumor types ${ }^{[42,105-108]}$, since there is both evidence of IL-15R expression and involvement in tumoral progression (Table 2). Normal kidney expresses a functional IL-15 receptor ${ }^{[109]}$ and human RCC expresses an IL-15R that seems to be directly involved in renal tumoral progression ${ }^{[110]}$. In pediatric ALL, high IL-15 expression correlates with CNS involvement $^{[111]}$, but those children with high IL-15Ra expression have a significantly better probability of survival at 5 years ${ }^{[112]}$. Mice that have transgenic overexpression of IL-15 also develop a fatal large granular leukemia $^{[113]}$. 
Besides directly stimulating tumor growth, IL-15 may also enhance endogenous immunosuppressive pathways. Umbilical cord blood-derived Tregs stimulated with IL-2 and IL-15 express higher levels of Cytotoxic T Lymphocyte Antigen-4 (CTLA-4), glucocorticoid-induced tumor necrosis factor receptor superfamily member number 18 (GITR), membrane bound Transforming Growth Factor (TGF)-beta and FOXp3, leading to higher production of IL-10 and TGF-beta ${ }^{[114]}$. Even Tregs from peripheral blood can be generated and sustained partially with IL-15 in the absence of IL-2 ${ }^{[115,116]}$. After allogeneic HSCT, transpresentation of donor-derived IL-15 is needed for acute GVHD but not for GVL effects ${ }^{[117]}$. Given the described effects of IL-15 in sustaining memory T cells, there is concern that IL-15 could potentiate GVHD by supporting alloreactive memory $\mathrm{T}$ cells ${ }^{[118]}$ and IL-15 has been shown to exacerbate xenogeneic GVHD ${ }^{[19]}$. Lastly there is an extensive literature on the effects of IL-15 on total body fat mass as well as promoting autoimmunity ${ }^{[69]}$. As is the case with IL-7, there is great promise for enhancing anti-tumor immunity with IL-15, but the potential to signal tumors and possibly Tregs, as well as to the potential for induction of autoimmunity, remain valid concerns.

\section{Interleukin-21:}

Background: IL-21 is homologous to IL-15, but the receptor for IL-21 is comprised of a unique subunit designated IL-21Ra and the IL-2Rgamma(c) $)^{[120,121]}$ and there is no evidence that IL-21 requires transpresentation for biologic activity. IL-21Ra is expressed on most mature lymphocyte populations (Fig. 1). Production of IL-21 is restricted to activated $\mathrm{CD}^{+} \mathrm{T}$ helper cells ${ }^{[122,123]}$. IL-21 appears to play important roles in modulating responses of lymphocytes to other cytokines. While IL-21 alone does not affect receptor expression, IL-21 can synergize with IL-2 to upregulate several surface receptors, including NKG2A, $\mathrm{CD} 25, \mathrm{CD} 86$ and $\mathrm{CD} 69^{[124]}$. In certain tumor models IL-21-enhanced tumor rejection is NKG2D dependent ${ }^{[125]}$, however IL-21 does not support NK cells and in fact, has been shown to limit NK cell expansion and induce apoptosis ${ }^{[126,127]}$. IL-21 alone does not induce $\mathrm{T}$ cell proliferation, however IL-21 can enhance the effects of other stimuli of proliferation, such as other gamma(c) cytokines ${ }^{[128-130]}$. IL-21 also has a role in B cell proliferation ${ }^{[128]}$ but may uniquely also induce $B$ cell apoptosis ${ }^{[131]}$. IL-21 has also been shown to induce IL-10 production in models of lupus, suggesting that like IL-2, it can also contribute to immunosuppressive activity ${ }^{[132]}$. Thus, the available pre-clinical data would suggest that IL-21 may work best in combination with other gamma(c) cytokines in the adjuvant setting.

Clinical trials with IL-21: There have been 3 clinical trials with IL-21. In a phase I trial of 43 patients with metastatic melanoma and RCC, IL-21 was administered in two 5-day cycles on days 1 through 5 and 15-19, of a treatment course. Doses ranged from 3$100 \mathrm{ug} \mathrm{kg}^{-1}$ dose $^{-1}$ and an expanded cohort was treated at the MTD, estimated to be $30 \mathrm{ug} \mathrm{kg}^{-1}$. Twenty-eight patients were treated in the expanded cohort. Twelve patients received up to five additional two-cycle courses of treatment without cumulative toxicity, except for one patient with reversible grade IV hepatotoxicity. Antitumor activity was observed in both melanoma (1CR, 4\%) and RCC (4PR, 21\%) ${ }^{[133]}$.

In another open-label, two-arm, dose escalation phase I trial of IL-21 involving 29 patients with metastatic melanoma, dose levels from 1-100 ug kg-1 were utilized in two parallel treatment regimens: Thrice weekly for 6 weeks (3/week) or three cycles of daily dosing for 5 days followed by 9 days of rest $(5+9)$. The MTD was also $30 \mathrm{ug} \mathrm{kg}^{-1}$ for both regimens. One PR was observed after the 3/week regimen and became a CR 3 months later ${ }^{[134]}$.

In a phase II, open-label, single-arm, two-stage trial study of IL-21 (30 ug $\mathrm{kg}^{-1}$ dose $\left.^{-1}\right)$ was administered in 8 week cycles $(5+9)$ in patients with metastatic melanoma. No toxicity was observed and the best tumor response included $1 \mathrm{CR}$ and $1 \mathrm{PR}$, both with lung metastases ${ }^{[135]}$. Pharmacodynamic studies show that IL-21 affects the serum levels of several cytokines, chemokines, acute-phase proteins and cell adhesion proteins in a dose-dependent fashion ${ }^{[136]}$. In the $(5+9)$ regimen, IL-21 induced a dose-dependent decrease in circulating NK cells and T cells, followed by a return to baseline in resting periods. In both CD8+ T cells and NK cells, up-regulation of perforin and granzyme B mRNA was observed. Finally, cytotoxicity assays showed that IL-21 enhanced the ability of NK cells to kill sensitive targets ex vivo ${ }^{[137]}$.

Potential antitumor applications of IL-21: IL-21 may have direct anti-tumor effects. For example, the majority of Chronic Lymphocytic Leukemia (CLL) patients have surface IL-21Ra, its expression correlates with apoptosis ${ }^{[107]}$ and IL-21 counteracts the proliferative and antiapoptotic signals delivered by IL15 to CLL B cells ${ }^{[138]}$. In addition to its pro-apoptotic effect, IL-21 promotes NK cell-mediated antibodydependent cellular cytotoxicity against rituximabcoated CLL cells in vitro ${ }^{[139]}$. While follicular lymphoma cells show high levels of IL-21R, addition of 
the cytokine inhibits proliferation and induced apoptosis $^{[140]}$. Gene-modified melanoma cells that express IL-21 grow slower than nonmodified cells in vitro and in vivo ${ }^{[141]}$. IL-21 has also been shown to exert activities on vascular Endothelial Cells (ECs), leading to decreased angiogenesis related gene expression $^{[142]}$, decreased proliferation and sprouting of activated ECs after IL-21 treatment, disturbing vessel architecture and negatively affecting vessel outgrowth. A murine myeloma cell vaccine containing IL-21 plasmid DNA induced significant tumor regression and prolonged survival ${ }^{[143]}$. IL-21-secreting RENCA cells were efficiently rejected following subcutaneous injection into syngeneic mice ${ }^{[144]}$. Similar results were seen in a mouse bladder carcinoma genetically modified to express IL-21 ${ }^{[145]}$. Finally, using a glioblastoma transduced to express IL-21, $100 \%$ of the animals rejected the tumor and $76 \%$ of these animals survived a subsequent tumor re-challenge, while other transduced cytokine genes were not as effective ${ }^{[146]}$.

IL-21 may also improve the potency of effector cells and other gamma(c) cytokines. For instance, administering IL-21 locally to melanoma tumors enhanced the therapeutic effects of adoptively transferred gp100-specific T cells and was synergistic with IL-2, leading to an increased proliferation of local $\mathrm{CD}^{+} \mathrm{T}$ cells and decreased accumulation of Tregs within the tumor microenvironment ${ }^{[147]}$. IL-21 also improves expansion and effector function of gammadelta $\mathrm{T}$ cells and reverses expression of inhibitory receptors. IL-21 can be combined with IL-2 to enhance gamma-delta $\mathrm{T}$ cell-mediated antitumor responses ${ }^{[148]}$. Use of IL-21 and IL-2 in culture up-regulate cytokine production of activated tumor-draining lymph node cells and enhances their therapeutic efficacy against established pulmonary metastatic fibrosarcomas. Animals treated with combined IL-21 and IL-2 showed protective immunity against tumor rechallenge, with expansion of memory $\mathrm{T}$ cells, antibody production and significantly elevated serum levels of IFN-gamma and IL-10 $0^{[149]}$.

Besides enhancing IL-2 therapy, IL-21 may also improve the effectiveness of other cytokines and immunotherapies. Combining alpha interferon and IL21 increases $\mathrm{NK}$ cell and $\mathrm{CD}^{+}$T-cell-mediated cytotoxicity in an experimental model of RCC, leading to inhibition of tumor growth and an increased survival $^{[150]}$. IL-21 can also significantly augment IL-7induced expansion of cytotoxic $\mathrm{T}$ cells, possibly by preventing the cytokine-induced down-regulation of CD127 on antigen-stimulated $\mathrm{T}$ cells, results which suggest that IL-21 may also play a cooperative role with IL-7 in modulating primary $\mathrm{CD}^{+}$T-cell responses $^{[151]}$. Several monoclonal antibodies targeting TAAs also have improved antitumor activities in mice when used in combination with IL-2 $1^{[152]}$ and human NK cells cultured with IL-21 and human breast cancer cells coated with trastuzumab showed enhanced lytic activity ${ }^{[153]}$. Lastly, in regards to a pediatric tumor, vaccinating with IL-21-gene-modified cells in a syngeneic metastatic neuroblastoma model demonstrated a reduction of microvessels in late metastases from therapeutically vaccinated mice. A role of survivin as a tumor antigen was suggested since a specific $\mathrm{T}$ cell response against this antigen was induced $^{[154]}$.

Interestingly, the route of IL-21 administration may be critical. Whereas both Subcutaneous (SC) and Intraperitoneal (IP) routes of IL-21 administration significantly inhibit growth of small, established RCC and melanoma tumors, only SC therapy significantly inhibited the growth of large, established tumors. Greater bioavailability and significant drainage of IL-21 to regional lymph nodes was observed following SC administration, which could account for the apparent increase in anti-tumor activity. In the RCC model, SC administration of IL-21 led to a significantly higher density of tumor infiltrating $\mathrm{CD}^{+} \mathrm{T}$ cells compared to $\mathrm{IP}^{[155]}$.

Limitations to IL-21 therapy: As with the other gamma(c) cytokines, IL-21 receptor has been observed on multiple tumor types ${ }^{[156-158]}$ and IL-21 has contributed to tumoriogenesis (Table 2). IL-21 shows divergent effects depending on the cell origin: growth stimulation in B cell lymphoma cell lines and adult $\mathrm{T}$ cell leukemia/lymphoma cell lines but induction of apoptosis in follicular lymphoma ${ }^{[140]}$. IL-21 has also been implicated in the pathogenesis of autoimmunity in a number of models ${ }^{[159]}$. As with the other gamma(c) cytokines, care in selecting the relevant tumor types as well as care in not to enhance Treg activity or cause autoimmunity is warranted.

\section{CONCLUSION}

Although initial clinical trials using IL-2 as a vaccine adjuvant demonstrated only modest effects in the clinic, combination immunotherapies using newer gamma(c) cytokines to promote NK cell and T-cell expansion and effector function are promising strategies to enhance immunotherapy of tumors. A number of different vaccine strategies in both preclinical and clinical studies have shown potentiation with concomitant IL-7, IL-15 and IL-21. These results have involved various regimens of adjuvant cytokine 
therapy, with differences in dosing, time of administration and schedule leading to different outcomes. Further research is needed to determine the most potent vehicles of vaccination as well as effective doses and schedules for cytokine delivery. Combinations of cytokines may be warranted. Future T cell-based immunotherapies will likely combine regimens that optimize vaccination and/or adoptive cell therapy with growth-promoting cells that can augment anti-tumor immunity while limiting autoimmunity responses. Caution needs to be exercised that tumors themselves are not signaling by these cytokines so that relapse is not promoted and patients should be monitored for autoimmunity where possible.

\section{ACKNOWLEDGEMENT}

The content of this publication does not necessarily reflect the views of policies of the Department of Health and Human Services, nor does mention of trade names, commercial products, or organizations imply endorsement by the US government.

This research was supported by intramural research funds at the National Cancer Institute (CLM).

Conflict-of-interest disclosure: The researchers declare no competing financial interests.

\section{REFERENCES}

1. Fehniger, T.A., M.A. Cooper and M.A. Caligiuri, 2002. Interleukin-2 and interleukin-15: Immunotherapy for cancer. Cytokine Growth Factor Rev., 13:169-183. http://www.ncbi.nlm.nih.gov/pubmed/11900992

2. Waldmann, T.A., 2006. The biology of interleukin2 and interleukin-15: Implications for cancer therapy and vaccine design. Nature Rev. Immunol., 6: 595-601.

http://www.nature.com/nri/journal/v6/n8/abs/nri19 01.html

3. Zhang, H., K.S. Chua and M. Guimond et al., 2005. Lymphopenia and interleukin-2 therapy alter homeostasis of CD4+CD25+ regulatory $\mathrm{T}$ cells. Nat. $\quad$ Med., 11: 1238-1243. http://www.ncbi.nlm.nih.gov/pubmed/16227988

4. Chapman, P.B., 2008. Combining a peptide vaccine with high-dose interleukin-2. J. Clin. Oncol., 26: 2250-2251. http://www.ncbi.nlm.nih.gov/pubmed/18467715

5. Coppin, C., 2008. Immunotherapy for renal cell cancer in the era of targeted therapy. Expert Rev. Anticancer Ther., 8: 907-919. http://www.ncbi.nlm.nih.gov/pubmed/18533800
6. Rosenberg, S.A., J.C. Yang and D.J. Schwartzentruber et al., 1998. Immunologic and therapeutic evaluation of a synthetic peptide vaccine for the treatment of patients with metastatic melanoma. Nature Med., 4: 321-327. http://www.ncbi.nlm.nih.gov/pubmed/9500606

7. Rosenberg, S.A., J.C. Yang and D.J. Schwartzentruber et al., 1999. Impact of cytokine administration on the generation of antitumor reactivity in patients with metastatic melanoma receiving a peptide vaccine. J. Immunol., 163: 1690-1695. http://www.pubmedcentral.nih.gov/articlerender.fc gi ?artid=2249693

8. Roberts, J.D., D. Niedzwiecki and W.E. Carson et al., 2006. Phase 2 study of the g209-2M melanoma peptide vaccine and low-dose interleukin-2 in advanced melanoma. J. Immunotherapy, 29: 95-101. http://www.ncbi.nlm.nih.gov/pubmed/16365605

9. Sosman, J.A., C. Carrillo, W.J. Urba et al., 2008. Three phase II cytokine working group trials of gp100 (210M) peptide plus high-dose interleukin-2 in patients with HLA-A2-positive advanced melanoma. J. Clin. Oncol., 26: 2292-2298. http://www.ncbi.nlm.nih.gov/pubmed/18467720

10. Slingluff, C.L., G.R. Petroni and G.V. Yamshchikov et al., 2004. Immunologic and clinical outcomes of vaccination with a multiepitope melanoma peptide vaccine plus low-dose interleukin-2 administered either concurrently or on a delayed schedule. J. Clin. Oncol., 22: 4474-4485. DOI: 10.1200/JCO.2004.10.212

11. Hersey, P., G. Halliday, M. Farrelly, C. DeSilva, M. Lett and S. Menzies, 2008. Phase I/II study of treatment with matured dendritic cells with or without low dose IL-2 in patients with disseminated melanoma. Cancer Immunol. Immunotherapy, 57: 1039-1051. http://www.ncbi.nlm.nih.gov/pubmed/18157724

12. Panelli, M.C., J. Wunderlich and J. Jeffries, et al., 2000. Phase 1 study in patients with metastatic melanoma of immunization with dendritic cell presenting epitopes derived from the melanomaassociated antigens MART-1 and gp100. J. Immunotherapy, 23: 487-498. http://cat.inist.fr/?aModele $=$ afficheN\&cpsidt $=1430$ 817

13. Redman, B.G., A.E. Chang and J. Whitfield et al., 2008. Phase IB trial assessing autologous, tumorpulsed dendritic cells as a vaccine administered with or without IL-2 in patients with metastatic melanoma. J. Immunotherapy, 31: 591-598. http://www.ncbi.nlm.nih.gov/pubmed/18528294 
14. Nagayama, H., K. Sato and M. Morishita et al., 2003. Results of a phase I clinical study using autologous tumor lysate-pulsed monocyte-derived mature dendritic cell vaccinations for stage IV malignant melanoma patients combined with low dose interleukin-2. Melanoma Res., 13: 521-530. http://direct.bl.uk/bld/PlaceOrder.do?UIN=137327 $593 \&$ ETOC $=$ RN $\&$ from $=$ searchengine

15. Haenssle, H., S.W. Krause and S. Emmert et al., 2004. Hydrid cell vaccination in metastatic melanoma: Clinical and immunologic results of a phase I/II study. J. Immunother., 27: 147-155. http://cat.inist.fr/?aModele $=$ afficheN\&cpsidt $=1557$ 0299

16. Escobar, A., M. Lopez and A. Serrano et al., 2005. Dendritic cell immunizations alone or combined with low doses of interleukin-2 induce specific immune responses in melanoma patients. Clin. Exp. Immunol., 142: 555-568. DOI: 10.1111/j.1365-2249.2005.02948.x

17. Wei, Y., R.P. Sticca and L.M. Holmes et al., 2006. Dendritoma vaccination combined with low dose interleukin-2 in metastatic melanoma patients induced immunological and clinical responses. Int. J. Oncol., 28: 585-593. http://www.spandidospublications.com/ijo/28/3/585

18. Powell, D.J., M.E. Dudley, K.A. Hogan, J.R. Wunderlich and S.A. Rosenberg, 2006. Adoptive transfer of vaccine-induced peripheral blood mononuclear cells to patients with metastatic melanoma following lymphodepletion. J. Immunol., 177: 6527-6539. http://www.jimmunol.org/cgi/content/abstract/177/ $9 / 6527$

19. Lotem, M., E. Shiloni and I. Pappo et al., 2004. Interleukin-2 improves tumor response to DNPmodified autologous vaccine for the treatment of metastatic malignant melanoma. Br. J. Cancer, 90: 773-780.

http://www.ncbi.nlm.nih.gov/pubmed/14970852

20. Rosenberg, S., Y. Zhai and J. Yang et al., 1998. Immunizing patients with metastatic melanoma using recombinant adenoviruses encoding MART1 or gp100 melanoma antigens. J. Natl. Cancer Inst., 90: 1894-1900.

http://www.ncbi.nlm.nih.gov/pubmed/9862627

21. Rosenberg, S.A., J.C. Yang and D.J. Schwartzentruber et al., 2003. Recombinant fowlpox viruses encoding the anchor-modified gp100 melanoma antigen can generate antitumor immune responses in patients with metastatic melanoma. Clin. Cancer Res., 9: 2973-2980. http://www.ncbi.nlm.nih.gov/pubmed/12912944
22. Dudek, A.Z., M.F. Mescher and I. Okazaki et al., 2008. Autologous large multivalent immunogen vaccine in patients with metastatic melanoma and renal cell carcinoma. Am. J. Clin. Oncol. Cancer Clin. $\quad$ Trial., $\quad 1$ 173-181. http://cat.inist.fr $/$ ?aModele $=$ afficheN\&cpsidt $=2030$ 6783

23. Nicholson, S., K. Guile and J. John et al., 2003. A randomized phase II trial of SRL172 (Mycobacterium vaccae) +/- low-dose interleukin2 in the treatment of metastatic malignant melanoma. Melanoma Res., 13: 389-393. http://www.ncbi.nlm.nih.gov/pubmed/12883365

24. Smith, F.O., S.G. Downey and J.A. Klapper et al., 2008. Treatment of metastatic melanoma using interleukin-2 alone or in conjunction with vaccines. Clin. Cancer Res., 14: 5610-5618. http://www.ncbi.nlm.nih.gov/pubmed/18765555

25. Rousseau, R.F., A.E. Haight, C.H. Jax et al., 2003. Local and systemic effects of an allogeneic tumor cell vaccine combining transgenic human lymphotactin with interleukin-2 in patients with advanced or refractory neuroblastoma. Blood, 101: 1718-1726.

http://www.ncbi.nlm.nih.gov/pubmed/12406881

26. Russell, H.V., D. Strother and Z. Mei et al., 2007. Phase I trial of vaccination with autologous neuroblastoma tumor cells genetically modified to secrete IL-2 and lymphotactin. J. Immunother., 30: 227-233.

http://www.ncbi.nlm.nih.gov/pubmed/17471169

27. Russell, H.V., D. Strother and Z. Mei et al., 2008. A phase $1 / 2$ study of autologous neuroblastoma tumor cells genetically modified to secrete IL-2 in patients with high-risk neuroblastoma. J. Immunother., $\quad 31$ : 812-819. http://www.ncbi.nlm.nih.gov/pubmed/18833006

28. Yu, A., A. Gilman and M. Ozkaynak et al., 2009. A phase III randomized trial of the chimeric antiGD2 antibody ch14.18 with GM-CSF and IL2 as immunotherapy following dose intensive chemotherapy for high-risk neuroblastoma: Children's Oncology Group (COG) study ANBL0032. J. Clin. Oncol., 27: abstr 10067z. http://www.curesearch.org/our_research/index_sub .aspx?id=7444

29. Dagher, R., L. Long and E. Read et al., 2002. Pilot trial of tumor-specific peptide vaccination and continuous infusion interleukin-2 in patients with recurrent Ewing sarcoma and alveolar rhabdomyosarcoma: An inter-institute NIH study. Med. Pediatr. Oncol., 38: 158-164. http://www.ncbi.nlm.nih.gov/pubmed/11836714 
30. Mackall, C.L., E.H. Rhee and E.J. Read et al., 2008. A pilot study of consolidative immunotherapy in patients with high-risk pediatric sarcomas. Clin. Cancer Res., 14: 4850-4858. http://cat.inist.fr/?aModele $=$ afficheN\&cpsidt $=2084$ 2243

31. Rousseau, R.F., E. Biagi and A. Dutour et al., 2006. Immunotherapy of high-risk acute leukemia with a recipient (autologous) vaccine expressing transgenic human CD40L and IL-2 after chemotherapy and allogeneic stem cell transplantation. Blood, 107: 1332-1341. http://www.pubmedcentral.nih.gov/articlerender.fc gi?artid=1895421

32. Mitchell, M.S., 2003. Immunotherapy as part of combinations for the treatment of cancer. Int. Immunopharmacol., $\quad 3$ : 1051-1059. http://www.ncbi.nlm.nih.gov/pubmed/12860162

33. Chianese-Bullock, K.A., E.M. Woodson and H. Tao et al., 2005. Autoimmune toxicities associated with the administration of antitumor vaccines and low-dose interleukin-2. J. Immunother., 28: 412-419. http://www.ncbi.nlm.nih.gov/pubmed/16000961

34. Strauchen, J.A. and B.A. Breakstone, 1987. IL-2 receptor expression in human lymphoid lesions. Immunohistochemical study of 166 cases. Am. J. Pathol., 126: 506-512.

http://www.pubmedcentral.nih.gov/articlerender.fc gi? artid=1899648

35. Sheibani, K., C.D. Winberg, S. van de Velde, D.W. Blayney and H. Rappaport, 1987. Distribution of lymphocytes with interleukin-2 receptors (TAC antigens) in reactive lymphoproliferative processes, Hodgkin's disease and non-Hodgkin's lymphomas. An immunohistol study of 300 cases. Am. J. Pathol., 127: 27-37. http://www.pubmedcentral.nih.gov/articlerender.fc gi?artid=1899594

36. Peuchmaur, M., D. Emilie and M.C. Crevon et al., 1990. IL-2 mRNA expression in Tac-positive malignant 1 ymphomas. Am. J. Pathol., 136: 383-390. http://www.pubmedcentral.nih.gov/articlerender.fc gi? artid=1877409

37. Olejniczak, K. and A. Kasprzak, 2008. Biological properties of interleukin 2 and its role in pathogenesis of selected diseases-a review. Med. Sci. Monitor, 14: RA179-189. http://cat.inist.fr/?aModele $=$ afficheN\&cpsidt $=2083$ 9827
38. Horiuchi, S., Y. Koyanagi and Y. Tanaka et al., 1997. Altered interleukin-2 receptor alpha-chain is expressed in human T-cell leukaemia virus type-Iinfected T-cell lines and human peripheral blood mononuclear cells of adult T-cell leukaemia patients through an alternative splicing mechanism. Immunologym, 91: 28-34. http://www.pubmedcentral.nih.gov/articlerender.fc gi? artid=1364031

39. Tsilivakos, V., A. Tsapis, S. Kakolyris, P. Iliakis, M. Perraki and V. Georgoulias, 1994. Characterization of interleukin 2 receptors on Bcell chronic lymphocytic leukemia cells. Leukemia, 8: 1571-1578. http://www.ncbi.nlm.nih.gov/pubmed/8090033

40. Lin, W.C., S. Yasumura and Y. Suminami et al., 1995. Constitutive production of IL-2 by human carcinoma cells, expression of IL-2 receptor and tumor cell growth. J. Immunol., 155: 4805-4816. http://www.jimmunol.org/cgi/content/abstract/155/ 10/4805

41. Kuhn, D.J. and Q.P. Dou, 2005. Direct inhibition of interleukin-2 receptor alpha-mediated signaling pathway induces G1 arrest and apoptosis in human head-and-neck cancer cells. J. Cell. Biochem., 95: 379-390.

http://www.biomedexperts.com/Abstract.bme/1577 9002/Direct_inhibition_of_interleukin-

2_receptor_alpha-

mediated_signaling_pathway_induces_G1_arrest_a nd_apoptosis_in_human_he

42. Marzec, M., K. Halasa and M. Kasprzycka et al., 2008. Differential effects of interleukin-2 and interleukin-15 versus interleukin-21 on CD4+ cutaneous T-Cell lymphoma cells. Cancer Res., 68: 1083-1091.

http://cancerres.aacrjournals.org/cgi/content/abstra ct/68/4/1083

43. Blattman, J.N., J.M. Grayson, E.J. Wherry, S.M. Kaech, K.A. Smith and R. Ahmed, 2003. Therapeutic use of IL-2 to enhance antiviral T-cell responses in vivo. Nat. Med., 9: 540-547. http://www.ncbi.nlm.nih.gov/pubmed/12692546

44. Fry, T.J. and C.L. Mackall, 2002. Interleukin-7: From bench to clinic. Blood, 99: 3892-3904. http://www.ncbi.nlm.nih.gov/pubmed/12010786

45. Guimond, M., R.G. Veenstra and D.J. Grindler et al., 2009. Interleukin 7 signaling in dendritic cells regulates the homeostatic proliferation and niche size of CD4+ T cells. Nat. Immunol., 10: 149-157. http://www.ncbi.nlm.nih.gov/pubmed/19136960 
46. Palmer, M.J., V.S. Mahajan, L.C. Trajman, D.J. Irvine, D.A. Lauffenburger and J. Chen, 2008. Interleukin7 receptor signaling network: An integrated systems perspective. Cell. Mol. Immunol., 5: 79-89. http://www.ncbi.nlm.nih.gov/pubmed/18445337

47. Capitini, C., A. Chisti, C. Mackall, 2009. Modulating T-cell homeostasis with IL-7: Preclinical and clinical studies. J. Int. Med. 266: 141-153. DOI: 10.1111/j.1365-2796.2009.02085.x

48. Rosenberg, S.A., C. Sportès and M. Ahmadzadeh et al., 2006. IL-7 administration to humans leads to expansion of $\mathrm{CD} 8+$ and $\mathrm{CD} 4+$ cells but a relative decrease of CD4+ T-regulatory cells. J. Immunother., 29: 313-319. http://www.pubmedcentral.nih.gov/articlerender.fc gi? artid=1473976

49. Sportes, C., F.T. Hakim and S.A. Memon et al., 2008. Administration of rhIL-7 in humans increases in vivo TCR repertoire diversity by preferential expansion of naive $\mathrm{T}$ cell subsets. J. Exp. Med., 205: 1701-1714. http://www.ncbi.nlm.nih.gov/pubmed/18573906

50. Möller, P., Y. Sun and T. Dorbic et al., 1998. Vaccination with IL-7 gene-modified autologous melanoma cells can enhance the anti-melanoma lytic activity in peripheral blood of patients with a good clinical performance status: A clinical phase I study. Br. J. Cancer, 77: 1907-1916. http://www.ncbi.nlm.nih.gov/pubmed/9667667

51. Pellegrini, M., T. Calzascia and A.R. Elford et al., 2009. Adjuvant IL-7 antagonizes multiple cellular and molecular inhibitory networks to enhance immunotherapies. Nat. Med., 15: 528-536. http://www.ncbi.nlm.nih.gov/pubmed/19396174

52. Colombetti, S., F. Levy and L. Chapatte, 2009. IL7 adjuvant treatment enhances long-term tumor antigen-specific CD8+ $\mathrm{T}$ cell responses following immunization with recombinant lentivectors. Blood, 113: 6629-6637. DOI: 10.1182/blood-200805-155309

53. Habibi, M., M. Kmieciak, L. Graham, J.K. Morales, H.D. Bear and M.H. Manjili, 2009. Radiofrequency thermal ablation of breast tumors combined with intralesional administration of IL-7 and IL-15 augments anti-tumor immune responses and inhibits tumor development and metastasis. Breast Cancer Res. Treat., 114: 423-431. http://www.pubmedcentral.nih.gov/articlerender.fc gi?artid=2649692

54. Wu, B., R.N. Shen, W.X. Wang, H.E. Broxmeyer and L. Lu, 1993. Antitumor effect of interleukin 7 in combination with local hyperthermia in mice bearing B16a melanoma cells. Stem. Cell., 11: 412-421. http://stemcells.alphamedpress.org/cgi/content/abst ract $/ 11 / 5 / 412$
55. Murphy, W.J., T.C. Back and K.C. Conlon et al., 1993. Antitumor effects of interleukin-7 and adoptive immunotherapy on human colon carcinoma xenografts. J. Clin. Investigat., 92: 1918-1924. http://www.pubmedcentral.nih.gov/articlerender.fc gi? artid $=288358$

56. Otto, M., R.C. Barfield and W.J. Martin et al., 2005. Combination Immunotherapy with clinicalscale enriched human $\{$ gamma $\{$ delta $\} \mathrm{T}$ cells, hu14.18 Antibody and the Immunocytokine Fc-IL7 in disseminated neuroblastoma. Clin. Cancer Res., 11: 8486-8491.

http://clincancerres.aacrjournals.org/cgi/reprint/11/ 23/8486

57. Mackall, C.L., T.J. Fry, C .Bare, P. Morgan, A. Galbraith and R.E. Gress, 2001. IL-7 increases both thymicdependent and thymic-independent T-cell regeneration after bone marrow transplantation. Blood, 97: 1491-1497. http://www.ncbi.nlm.nih.gov/pubmed/11222398

58. Cosenza, L., G. Gorgun, A. Urbano and F. Foss, 2002. Interleukin-7 receptor expression and activation in nonhaematopoietic neoplastic cell lines. Cell. Signall., 14: 317-325. DOI: 10.1016/S0898-6568(01)00245-5

59. Ming, J., Q. Zhang, X. Qiu and E. Wang, 2009. Interleukin 7/interleukin 7 receptor induce c-Fos/cJun-dependent vascular endothelial growth factorD up-regulation: A mechanism of lymphangiogenesis in lung cancer. Eur. J. Cancer, 45: 866-873. DOI: 10.1016/J.EJCA.2008.12.006

60. Brown, V.I., J. Fang and K. Alcorn et al., 2003. Rapamycin is active against B-precursor leukemia in vitro and in vivo, an effect that is modulated by IL-7-mediated signaling. Proc. Natl. Acad. Sci. USA., $\quad$ pp: 15113-15118. http://www.ncbi.nlm.nih.gov/pubmed/14657335

61. González-García, S., M. García-Peydró and E. Martín-Gayo et al., 2009. CSL-MAMLdependent Notch1 signaling controls $\mathrm{T}$ lineagespecific IL-7R\{alpha\} gene expression in early human thymopoiesis and leukemia. J. Exp. Med., 206: 779-791.

http://www.ncbi.nlm.nih.gov/pubmed/19349467

62. Cattaruzza, L., A. Gloghini and K. Olivo et al., 2009. Functional coexpression of Interleukin (IL)-7 and its receptor (IL-7R) on Hodgkin and ReedSternberg cells: Involvement of IL-7 in tumor cell growth and microenvironmental interactions of Hodgkin's lymphoma. Int. J. Cancer, 125: 1092-1101. http://www.ncbi.nlm.nih.gov/pubmed/19391137 
63. Korte, A., A. Möricke and B. Beyermann et al., 1999. Extensive alternative splicing of interleukin7 in malignant hematopoietic cells: Implication of distinct isoforms in modulating IL-7 activity. J. Interferon Cytokine Res., 19: 495-503. http://www.ncbi.nlm.nih.gov/pubmed/10386862

64. Vudattu, N.K., I. Magalhaes, H. Hoehn, D. Pan and M.J. Maeurer, 2008. Expression analysis and functional activity of interleukin-7 splice variants. Genes Immun., 10: 132-140. http://www.ncbi.nlm.nih.gov/pubmed/19092841

65. Dean, R.M., T. Fry and C. Mackall et al., 2008. Association of serum interleukin-7 levels with the development of acute graft-versus-host disease. J. Clin. Oncol., 26: 5735-5741. http://www.ncbi.nlm.nih.gov/pubmed/19001329

66. Sinha, M.L., T.J. Fry, D.H. Fowler, G. Miller and C.L. Mackall, 2002. Interleukin 7 worsens graftversus-host disease. Blood, 100: 2642-2649. http://www.ncbi.nlm.nih.gov/pubmed/12239180

67. Snyder, K.M., C.L. Mackall and T.J. Fry, 2006. IL7 in allogeneic transplant: Clinical promise and potential pitfalls. Leukemia Lymphoma, 47: 1222-1228. http://www.ncbi.nlm.nih.gov/pubmed/16923550

68. Roato, I., G. Brunetti and E. Gorassini et al., 2006. IL-7 up-regulates TNF-[alpha]-dependent osteoclastogenesis in patients affected by solid tumor. PLoS One, 1: e124. http://www.ncbi.nlm.nih.gov/pubmed/17205128

69. Budagian, V., E. Bulanova, R. Paus and S.B. Paus, 2006. IL-15/IL-15 receptor biology: A guided tour through an expanding universe. Cytokine Growth Factor Rev., 17: 259-280. http://cat.inist.fr/?aModele $=$ afficheN\&cpsidt $=1798$ 6039

70. Oh, S., L.P. Perera, D.S. Burke, T.A. Waldmann and J.A. Berzofsky, 2004. IL-15/IL-15Ralphamediated avidity maturation of memory CD8+ T cells. Proc. Natl. Acad. Sci. USA., 101: 15154-15159. http://www.biomedexperts.com/Abstract.bme/1547 7598/IL-15_IL-15Ralpha-

mediated_avidity_maturation_of_memory_CD8_T _cells

71. Huntington, N.D., N. Legrand and N.L. Alves et al., 2008. IL-15 trans-presentation promotes human NK cell development and differentiation in vivo. J. Exp. Med., 206: 25-34. http://jem.rupress.org/cgi/content/abstract/206/1/25

72. Stonier, S.W., L.J. Ma, E.F.Castillo and K.S. Schluns, 2008. Dendritic cells drive memory CD8 T-cell homeostasis via IL-15 transpresentation. Blood, 112: 4546-4554.

http://www.ncbi.nlm.nih.gov/pubmed/18812469
73. Daudt, L., R. Maccario and F. Locatelli et al., 2008. Interleukin-15 favors the expansion of central memory CD8+ T cells in ex vivo generated, antileukemia human cytotoxic $\mathrm{T}$ lymphocyte lines. J. Immunother., 31: 385-393. http://www.biomedexperts.com/Abstract.bme/1839 1757/Interleukin-

15_favors_the_expansion_of_central_memory_CD 8_T_cells_in_ex_vivo_generated_antileukemia_hu man_cytotoxic_T

74. Kokaji, A.I., D.L. Hockley and K.P. Kane, 2008. IL-15 transpresentation augments CD8+ $\mathrm{T}$ cell activation and is required for optimal recall responses by central memory CD8+ T cells. J. Immunol., 180: 4391-4401. http://www.ncbi.nlm.nih.gov/pubmed/18354159

75. Huntington, N.D., H. Puthalakath and P. Gunn et al., 2007. Interleukin 15-mediated survival of natural killer cells is determined by interactions among Bim, Noxa and Mcl-1. Nat. Immunol., 8: 856-863. http://www.ncbi.nlm.nih.gov/pubmed/17618288

76. Ozdemir, O. and S. Savasan, 2005. Combinational IL-2/IL-15 induction does not further enhance IL15-induced lymphokine-activated killer cell cytotoxicity against human leukemia/lymphoma cells. Clin. Immunol., 115: 240-249. DOI: 10.1016/j.clim.2005.01.008

77. Vallabhapurapu, S., S.P. Budnicka and M. Riemann et al., 2008. Rel/NF-kappaB family member RelA regulates NK1.1- to $\mathrm{NK} 1.1+$ transition as well as IL-15-induced expansion of NKT cells. Eur. J. Immunol., 38: 3508-3519. http://www.ncbi.nlm.nih.gov/pubmed/19003818

78. Ullrich, E., M. Bonmort and G. Mignot et al., 2008. Trans-presentation of IL-15 dictates IFNproducing killer dendritic cells effector functions. J. Immunol., 180: 7887-7897. http://www.ncbi.nlm.nih.gov/pubmed/18523252

79. Mignot, G., E. Ullrich and M. Bonmort et al., 2008. The critical role of IL-15 in the antitumor effects mediated by the combination therapy imatinib and IL-2. J. Immunol., 180: 6477-6483. http://www.ncbi.nlm.nih.gov/pubmed/18453565

80. Nakazato, K., H.Yamada, T. Yajima, Y. Kagimoto, H. Kuwano and Y. Yoshikai, 2007. Enforced expression of Bcl-2 partially restores cell numbers but not functions of TCR $\{$ gamma $\}\{$ delta $\}$ intestinal intraepithelial $\mathrm{T}$ lymphocytes in IL-15deficient mice. J. Immunol., 178: 757-764. http://www.ncbi.nlm.nih.gov/pubmed/17202336

81. Zhao, H., H. Nguyen and J. Kang, 2005. Interleukin 15 controls the generation of the restricted $\mathrm{T}$ cell receptor repertoire of [gamma][delta] intestinal intraepithelial lymphocytes. Nat. Immunol., 6: 1263-1271. http://www.ncbi.nlm.nih.gov/pubmed/16273100 
82. Gill, N., G. Paltser and A.A. Ashkar, 2009. Interleukin-15 expression affects homeostasis and function of $\mathrm{B}$ cells through $\mathrm{NK}$ cell-derived interferon-[gamma]. Cell. Immunol., 258: 59-64. DOI: 10.1016/j.cellimm.2009.03.010

83. Abdel-Salam, B.K.A.H. and H. Ebaid, 2008. Upregulation of major histocompatibility complex class II, CD83, CD64 and CD14 on polymorphonuclear neutrophils stimulated with interleukin-15. J. Microbiol. Immunol. Infect., 41: 462-468.

http://www.ncbi.nlm.nih.gov/pubmed/19255689

84. Brilot, F., T. Strowig, S.M. Roberts, F. Arrey and C. Münz, 2007. NK cell survival mediated through the regulatory synapse with human DCs requires IL-15Ralpha. J. Clin. Invest., 117: 3316-3329. http://cat.inist.fr/?aModele $=$ afficheN\&cpsidt $=19213387$

85. Lucas, M., W. Schachterlle, K. Oberle, P. Aichele and A. Diefenbach, 2007. Dendritic cells prime natural killer cells by trans-presenting interleukin 15. Immunity, 26: 503-517. http://www.ncbi.nlm.nih.gov/pubmed/17398124

86. Fujisaki, H., H. Kakuda and N. Shimasaki et al., 2009. Expansion of highly cytotoxic human natural killer cells for cancer cell therapy. Cancer Res., 69: 4010-4017.

http://www.ncbi.nlm.nih.gov/pubmed/19383914

87. Fujisaki, H., H. Kakuda, C. Imai, C. Mullighan and D. Campana, 2009. Replicative potential of human natural killer cells. Br. J. Haematol., 145: 606-613. DOI: 10.1111/j.1365-2141.2009.07667.x

88. Numbenjapon, T., L.M. Serrano, W.C. Chang, S.J. Forman, M.C. Jensen and L.J.N. Cooper, 2007. Antigen-independent and antigen-dependent methods to numerically expand CD19-specific CD8+ T cells. Experim. Hematol., 35: 1083-1090. http://cat.inist.fr/?aModele $=$ afficheN\&cpsidt $=18891004$

89. Tang, F., L.T. Zhao, Y. Jiang, D.N. Ba, L.X. Cui and W. He, 2008. Activity of recombinant human interleukin-15 against tumor recurrence and metastasis in mice. Cell. Mol. Immunol., 5: 189-196. http://www.curehunter.com/public/pubmed18582400.do

90. Zhang, M., Z. Yao, S. Dubois, W. Ju, Muller JrR and T.A. Waldmann, 2009. Interleukin-15 combined with an anti-CD40 antibody provides enhanced therapeutic efficacy for murine models of colon cancer. Proc. Natl. Acad. Sci., 106: 7513-7518. http://www.ncbi.nlm.nih.gov/pubmed/19383782

91. Vera, M., N. Razquin, J. Prieto, I. Melero, P. Fortes and G. Gonzalez-Aseguinolaza, 2005. Intratumoral injection of dendritic cells transduced by an sv40based vector expressing interleukin-15 induces curative immunity mediated by CD8+ $\mathrm{T}$ lymphocytes and NK cells. Mol. Ther., 12: 950-959. http://www.ncbi.nlm.nih.gov/pubmed/15921960
92. Sasahira, T., T. Sasaki and H. Kuniyasu, 2005. Interleukin-15 and transforming growth factor alpha are associated with depletion of tumorassociated macrophages in colon cancer. J. Exp. Clin. Cancer Res., 24: 69-74. http://www.ncbi.nlm.nih.gov/pubmed/15943034

93. Ugen, K.E., M.A. Kutzler and B. Marrero et al., 2006. Regression of subcutaneous B16 melanoma tumors after intratumoral delivery of an IL-15expressing plasmid followed by in vivo electroporation. Cancer Gene. Ther., 13: 969-974. http://www.ncbi.nlm.nih.gov/pubmed/16763607

94. Epardaud, M., K.G. Elpek and M.P. Rubinstein et al., 2008. Interleukin-15/Interleukin-15R \{alpha complexes promote destruction of established tumors by reviving tumor-resident CD8+ T cells. Cancer Res., 68: 2972-2983. http://www.ncbi.nlm.nih.gov/pubmed/18413767

95. Le, H., L. Graham, C. Miller, M. Kmieciak, M. Manjili and H. Bear, Incubation of antigensensitized $\mathrm{T}$ lymphocytes activated with bryostatin $1+$ ionomycin in IL-7 + IL-15 increases yield of cells capable of inducing regression of melanoma metastases compared to culture in IL-2. Cancer Immunol. Immunotherapy. http://www.ncbi.nlm.nih.gov/pubmed/19198835

96. Basak, G.W., L. Zapala, P.J. Wysocki, A. Mackiewicz, M. Jakóbisiak and W. Lasek, 2008. Interleukin 15 augments antitumor activity of cytokine genemodified melanoma cell vaccines in a murine model. Oncol. Rep., 19: 1173-1179. http://cat.inist.fr/?aModele $=$ afficheN\&cpsidt $=20320525$

97. Verhoeven, D.H.J., A.S.K. de Hooge and E.C.K. Mooiman et al., 2008. NK cells recognize and lyse Ewing sarcoma cells through NKG2D and DNAM-1 receptor dependent pathways. Mol. Immunol., 45: 3917-3925. http://www.ncbi.nlm.nih.gov/pubmed/18657862

98. Castriconi, R., A. Daga and A. Dondero et al., 2009. NK cells recognize and kill human glioblastoma cells with stem cell-like properties. J. Immunol., $\quad$ 182: 3530-3539. http://www.ncbi.nlm.nih.gov/pubmed/19265131

99. King, J.W., S.Thomas and F. Corsi et al., 2009. IL15 Can reverse the unresponsiveness of wilms' tumor antigen-specific CTL in patients with prostate cancer. Clin. Cancer Res., 15: 1145-1154. http://www.ncbi.nlm.nih.gov/pubmed/19228720

100.Teague, R.M., B.D. Sather and J.A. Sacks et al., 2006. Interleukin-15 rescues tolerant CD8+ T cells for use in adoptive immunotherapy of established tumors. Nat. Med., 12: 335-341. http://www.ncbi.nlm.nih.gov/pubmed/16474399 
101.Melchionda, F., T.J. Fry, M.J. Milliron, M.A. McKirdy, Y. Tagaya and C.L. Mackall, 2005. Adjuvant IL-7 or IL-15 overcomes immunodominance and improves survival of the CD8+ memory cell pool. J. Clin. Invest., 115: 1177-1187.

http://www.ncbi.nlm.nih.gov/pubmed/15841203

102.Boyiadzis, M., S. Memon, J. Carson et al., 2008. Up-regulation of $\mathrm{NK}$ Cell activating receptors following allogeneic hematopoietic stem cell transplantation under a lymphodepleting reduced intensity regimen is associated with elevated IL15 Levels. Biol. Blood Marrow Transplant., 14: 290-300. http://www.ncbi.nlm.nih.gov/pubmed/18275895

103. Chen, G., D. Wu and Y. Wang et al., 2008. Expanded donor natural killer cell and IL-2, IL-15 treatment efficacy in allogeneic hematopoietic stem cell transplantation. Eur. J. Haematol., 81: 226-235. http://www.ncbi.nlm.nih.gov/pubmed/18573173

104.Alpdogan, O., J.M. Eng and S.J. Muriglan et al., 2005. Interleukin-15 enhances immune reconstitution after allogeneic bone marrow transplantation. Blood, 105: 865-873. http://www.ncbi.nlm.nih.gov/pubmed/15280205

105.Zambello, R., M. Facco and L. Trentin et al., 1997. Interleukin-15 Triggers the proliferation and cytotoxicity of granular lymphocytes in patients with lymphoproliferative disease of granular lymphocytes. $\quad$ Blood, 89: 201-211. http://www.biomedexperts.com/Abstract.bme/8978 293/Interleukin-

15_triggers_the_proliferation_and_cytotoxicity_of _granular_lymphocytes_in_patients_with_lymphop roliferative

106.Zhang, R., M.V. Shah and J. Yang et al., 2008. Network model of survival signaling in large granular lymphocyte leukemia. Proc. Natl. Acad. Sci. USA., 105: 16308-16313. http://www.ncbi.nlm.nih.gov/pubmed/18852469

107.de Totero, D., R. Meazza and M. Capaia et al., 2008. The opposite effects of IL-15 and IL-21 on CLL B cells correlate with differential activation of the JAK/STAT and ERK1/2 pathways. Blood, 111: $517-524$. http://www.ncbi.nlm.nih.gov/pubmed/17938255

108. Badoual, C., G. Bouchaud and N.E.H. Agueznay et al., 2008. The soluble $\{$ alpha $\}$ chain of interleukin-15 receptor: A proinflammatory molecule associated with tumor progression in head and neck cancer. Cancer Res., 68: 3907-3914. http://cancerres.aacrjournals.org/cgi/content/abstra ct/68/10/3907
109.Tejman-Yarden, N., M. Zlotnik, E. Lewis, O. Etzion, C. Chaimovitz and A. Douvdevani, 2005. Renal cells express a functional interleukin-15 receptor. Nephrol. Dial. Transplant., 20: 516-523. http://www.ncbi.nlm.nih.gov/pubmed/15671076

110. Khawam, K., J. Giron-Michel and Y. Gu et al., 2009. Human renal cancer cells express a novel membrane-bound interleukin-15 that induces, in response to the soluble interleukin-15 Receptor \{alpha\} chain, epithelial-to-mesenchymal transition. Cancer Res., 69: 1561-1569. http://cancerres.aacrjournals.org/cgi/content/abstra ct/69/4/1561

111.Cario, G., S. Izraeli and A. Teichert et al., 2007. High interleukin-15 expression characterizes childhood acute lymphoblastic leukemia with involvement of the CNS . J. Clin. Oncol., 25: 4813-4820.

http://www.ncbi.nlm.nih.gov/pubmed/17947730

112.Wu, S., R. Geflner, A. von Stackelberg, R. Kirchner, G. Henze and K. Seeger, 2005. Cytokine/cytokine receptor gene expression in childhood acute lymphoblastic leukemia. Cancer, 103: 1054-1063. http://www.ncbi.nlm.nih.gov/pubmed/15651075

113.Fehniger, T.A., K. Suzuki and A. Ponnappan et al., 2001. Fatal leukemia in interleukin 15 transgenic mice follows early expansions in natural killer and memory phenotype CD8+ T Cells. J. Exp. Med., 193: 219-232. http://www.ncbi.nlm.nih.gov/pubmed/11208862

114.Lee, C., S. Lin, P. Cheng and M. Kuo, 2009. The regulatory function of umbilical cord blood CD4+CD25+ $\mathrm{T}$ cells stimulated with antiCD3/anti-CD28 and exogenous interleukin (IL)-2 or IL-15. Pediatr. Allergy Immunol. http://www.tripdatabase.com/SearchLander.html?s $=1 \& \mathrm{gk}=$ The+regulatory+function+of +umbilical+c ord+blood+\&itemId=862399

115.Vang, K.B., J. Yang, S.A. Mahmud, M.A. Burchill, A.L. Vegoe and M.A. Farrar, 2008. IL-2, -7 and 15 , but not thymic stromal lymphopoeitin, redundantly govern $\mathrm{CD} 4+$ Foxp3+ regulatory $\mathrm{t}$ cell development. J. Immunol., 181: 3285-3290. http://www.jimmunol.org/cgi/content/abstract/181/ $5 / 3285$

116.Imamichi, H., I. Sereti and H.C. Lane, 2008. IL15 acts as a potent inducer of CD4 (+)CD25(hi) cells expressing FOXP3. Eur. J. Immunol., $\quad 38$ : 1621-1630. http://www.ncbi.nlm.nih.gov/pubmed/18493981

117.Blaser, B.W., N.R. Schwind and S. Karol et al., 2006. Trans-presentation of donor-derived interleukin 15 is necessary for the rapid onset of acute graft-versus-host disease but not for graftversus-tumor activity. Blood, 108: 2463-2469. http://www.pubmedcentral.nih.gov/articlerender.fc gi? artid=1895554 
118.Blaser, B.W., S. Roychowdhury and D.J. Kim et al., 2005. Donor-derived IL-15 is critical for acute allogeneic graft-versus-host disease. Blood, 105: 894-901.

http://cat.inist.fr/?aModele=afficheN\&cpsidt $=16550063$

119. Roychowdhury, S., B.W. Blaser, A.G. Freud et al., 2005. IL-15 but not IL-2 rapidly induces lethal xenogeneic graft-versus-host disease. Blood, 106: 2433-2435.

http://www.ncbi.nlm.nih.gov/pubmed/15976176

120.Habib, T., S. Senadheera, K. Weinberg and K. Kaushansky, 2002. The common gamma chain (gamma c) is a required signaling component of the IL-21 receptor and supports IL-21-induced cell proliferation via JAK3. Biochemistry, 41: 8725-8731. http://www.ncbi.nlm.nih.gov/pubmed/12093291

121. Asao, H., C. Okuyama and S. Kumaki et al., 2001. Cutting edge: The common gamma-chain is an indispensable subunit of the IL-21 receptor complex. J. Immunol., 167: 1-5. http://www.ncbi.nlm.nih.gov/pubmed/11418623

122. Wurster, A.L., V.L. Rodgers and A.R. Satoskar et al., 2002. Interleukin 21 is a $\mathrm{T}$ helper (Th) cell 2 cytokine that specifically inhibits the differentiation of naive $\mathrm{Th}$ cells into interferon gamma-producing Th1 cells. J. Exp. Med., 196: 969-977.

http://www.jem.org/cgi/content/abstract/196/7/969

123. Mehta, D.S., A.L. Wurster, A.S. Weinmann and M.J. Grusby, 2005. NFATc2 and T-bet contribute to T-helper-cell-subset-specific regulation of IL21 expression. Proc. Natl. Acad. Sci. USA., 102: 2016-2021.

http://www.pubmedcentral.nih.gov/articlerender.fc gi? artid=548571

124.Skak, K., K. Frederiksen and D. Lundsgaard, 2008. Interleukin-21 activates human natural killer cells and modulates their surface receptor expression. Immunology, 123: 575-583. http://www.pubmedcentral.nih.gov/articlerender.fc gi? $\operatorname{artid}=2433320$

125.Takaki, R., Y. Hayakawa, A. Nelson et al., 2005. IL-21 Enhances tumor rejection through a NKG2D-dependent mechanism. J. Immunol., 175: 2167-2173.

http://www.ncbi.nlm.nih.gov/pubmed/16081783

126.Wang, G., M. Tschoi and R. Spolski et al., 2003. In vivo antitumor activity of interleukin 21 mediated by natural killer cells. Cancer Res., 63: 9016-9022.

http://cat.inist.fr/?aModele $=$ afficheN\&cpsidt $=15382654$
127.Kasaian, M.T., M.J. Whitters and L.L. Carter et al., 2002. IL-21 limits NK cell responses and promotes antigen-specific $\mathrm{T}$ cell activation: $\mathrm{A}$ mediator of the transition from innate to adaptive immunity. Immunity, 6: 559-569. http://www.ncbi.nlm.nih.gov/pubmed/11970879

128.Parrish-Novak, J., S.R. Dillon and A. Nelson et al., 2000. Interleukin 21 and its receptor are involved in NK cell expansion and regulation of lymphocyte function. Nature, 408: 57-63. http://www.nature.com/nature/journal/v408/n6808/ abs/408057a0.html

129.Zeng, R., Spolski, R. and S.E. Finkelstein et al., 2005. Synergy of IL-21 and IL-15 in regulating CD8+ T cell expansion and function. J. Exp. Med., 201: 139-148.

http://www.ncbi.nlm.nih.gov/pubmed/15630141

130. Van Leeuwen, E.M., L.E. Gamadia, P.A. Baars, E.B. Remmerswaal, I.J. Ten Berge and R.A. Van Lier, 2002. Proliferation requirements of cytomegalovirus-specific, effector-type human CD8+ T cells. J. Immunol., 169: 5838-5843. http://www.ncbi.nlm.nih.gov/pubmed/12421965

131. Mehta, D.S., A.L. Wurster, M.J. Whitters, D.A. Young, M. Collins and M.J. Grusby, 2003. IL-21 induces the apoptosis of resting and activated primary B cells. J. Immunol., 170: 4111-4118. http://www.ncbi.nlm.nih.gov/pubmed/12682241

132.Spolski, R., H.P. Kim, W. Zhu, D.E. Levy and W.J. Leonard, 2009. IL-21 mediates suppressive effects via its induction of IL-10. J. Immunol., 182: 2859-2867.

http://www.ncbi.nlm.nih.gov/pubmed/19234181

133.Thompson, J.A., B.D. Curti and B.G. Redman et al., 2008. Phase I study of recombinant interleukin-21 in patients with metastatic melanoma and renal cell carcinoma. J. Clin. Oncol., 26: 2034-2039. http://jco.ascopubs.org/cgi/content/abstract/26/12/2 034

134.Davis, I.D., B.K. Skrumsager and J. Cebon et al., 2007. An Open-label, two-arm, phase I trial of recombinant human interleukin-21 in patients with metastatic melanoma. Clin. Cancer Res., 13: 3630-3636. http://clincancerres.aacrjournals.org/cgi/content/ab stract/13/12/3630

135.Davis, I.D., B. Brady and R.F. Kefford et al., 2009. Clinical and biological efficacy of recombinant human interleukin-21 in patients with stage IV malignant melanoma without prior treatment: A phase IIa trial. Clin. Cancer Res., 15: 2123-2129. http://www.ncbi.nlm.nih.gov/pubmed/19276257

136.Dodds, M., K. Frederiksen and K. Skak et al., 2009. Immune activation in advanced cancer patients treated with recombinant IL-21: Multianalyte profiling of serum proteins. Cancer Immunol. Immunotherapy, 58: 843-854. http://www.ncbi.nlm.nih.gov/pubmed/18925392 
137.Frederiksen, K., D. Lundsgaard and J. Freeman et al., 2008. IL-21 induces in vivo immune activation of $\mathrm{NK}$ cells and $\mathrm{CD} 8+\mathrm{T}$ cells in patients with metastatic melanoma and renal cell carcinoma. Cancer Immunol. Immunother., 57: 1439-1449. http://www.pubmedcentral.nih.gov/articlerender.fc gi? artid=2491425

138.de Totero, D., R. Meazza and S. Zupo et al., 2006. Interleukin-21 receptor (IL-21R) is up-regulated by CD40 triggering and mediates proapoptotic signals in chronic lymphocytic leukemia B cells. Blood, 107: 3708-3715.

http://www.ncbi.nlm.nih.gov/pubmed/16391014

139. Gowda, A., J. Roda and S.R.A. Hussain et al., 2008. IL-21 mediates apoptosis through upregulation of the $\mathrm{BH} 3$ family member BIM and enhances both direct and antibody-dependent cellular cytotoxicity in primary chronic lymphocytic leukemia cells in vitro. Blood, 111: 4723-4730.

http://www.ncbi.nlm.nih.gov/pubmed/18182577

140.Akamatsu, N., Y. Yamada and H. Hasegawa et al., 2007. High IL-21 receptor expression and apoptosis induction by IL-21 in follicular lymphoma. Cancer Lett., 256: 196-206. http://cat.inist.fr/?aModele=afficheN\&cpsidt $=19137592$

141.Fang, L., K. Wang and X. Liu et al. 2008. A study on anti-tumor immunity induced by gene-modified melanoma B16 cells. Oncol. Rep., 19: 1589-1595. http://www.ncbi.nlm.nih.gov/pubmed/18497970

142.Hinrichs, C.S., R. Spolski and C.M. Paulos et al., 2008. IL-2 and IL-21 confer opposing differentiation programs to $\mathrm{CD} 8+\mathrm{T}$ cells for adoptive immunotherapy. Blood, 111: 5326-5333. http://bloodjournal.hematologylibrary.org/cgi/conte nt/short/111/11/5326

143.Dou, J., L. Chu and F. Zhao et al., 2007. Study of immunotherapy of murine myeloma by an IL-21based tumor vaccine in BALB/C mice. Cancer Biol. Therapy,6: 1871-1879. http://www.ncbi.nlm.nih.gov/pubmed/18059168

144. Kumano, M., I. Hara and J. Furukawa et al., 2007. Interleukin-21 activates cytotoxic $\mathrm{T}$ lymphocytes and natural killer cells to generate antitumor response in mouse renal cell carcinoma. J. Urol., 178:1 504-1509. DOI: 10.1016/j.juro.2007.05.115

145.Furukawa, J., I. Hara, H. Nagai, A. Yao, S. Oniki and M. Fujisawa, 2006. Interleukin-21 gene transfection into mouse bladder cancer cells results in tumor rejection through the cytotoxic $\mathrm{T}$ lymphocyte response. J. Urol., 176: 1198-1203. http://cat.inist.fr/?aModele $=$ afficheN\&cpsidt $=1803$ 5748
146.Daga, A., A. Orengo and R. Maria et al., 2007. Glioma immunotherapy by IL-21 gene-modified cells or by recombinant IL-21 involves antibody responses. Int. J. Cancer, 121: 1756-1763. http://www.ncbi.nlm.nih.gov/pubmed/17582604

147.Kim-Schulze, S., H.S. Kim, Q. Fan, D.W. Kim and H.L. Kaufman, 2009. Local IL-21 promotes the therapeutic activity of effector $t$ cells by decreasing regulatory $\mathrm{T}$ cells within the tumor microenvironment. Mol. Ther., 17: 380-388. http://www.ncbi.nlm.nih.gov/pubmed/19034262

148. Thedrez, A., C. Harly, A . Morice, S. Salot, M. Bonneville and E. Scotet, 2009. IL-21Mediated Potentiation of antitumor cytolytic and proinflammatory responses of human $\mathrm{V}$ \{gamma\}9V\{delta\}2 $\mathrm{T}$ cells for adoptive immunotherapy. J. Immunol., 182: 3423-3431. http://cat.inist.fr/?aModele $=$ afficheN\&cpsidt=21224523

149.Iuchi, T., S. Teitz-Tennenbaum and J. Huang et al., 2008. Interleukin-21 Augments the efficacy of Tcell therapy by eliciting concurrent cellular and humoral responses. Cancer Res., 68: 4431-4441. http://cancerres.aacrjournals.org/cgi/content/abstra ct/68/11/4431

150.Eriksen, K.W., H. Sndergaard and A. Woetmann et al., 2009. The combination of IL-21 and IFN[alpha] boosts STAT3 activation, cytotoxicity and experimental tumor therapy. Mol. Immunol., 46: 812-820. http://www.ncbi.nlm.nih.gov/pubmed/18947877

151.Liu, S., G. Lizee and Y. Lou et al., 2007. IL-21 synergizes with IL-7 to augment expansion and anti-tumor function of cytotoxic $\mathrm{T}$ cells. Int. Immunol., $\quad 19$ : 1213-1221. http://intimm.oxfordjournals.org/cgi/content/abstra ct/19/10/1213

152.Smyth, M.J., M.W.L. Teng and J. Sharkey et al., 2008. Interleukin 21 enhances antibody-mediated tumor rejection. Cancer Res., 68: 3019-3025. http://cancerres.aacrjournals.org/cgi/content/abstra ct/68/8/3019

153.Roda, J.M., R. Parihar, A. Lehman, A. Mani, S. Tridandapani and W.E. Carson, 2006. III. Interleukin-21 enhances $\mathrm{NK}$ cell activation in response to antibody-coated targets. J. Immunol., 177: $120-129$. http://www.ncbi.nlm.nih.gov/pubmed/16785506

154.Croce, M., R. Meazza and A. Orengo et al., 2008. Immunotherapy of neuroblastoma by an Interleukin-21-secreting cell vaccine involves survivin as antigen. Cancer Immunol. Immunother., 57: 1625-1634. http://www.ncbi.nlm.nih.gov/pubmed/18324400 
155.Søndergaard, H., K. Frederiksen and P. Thygesen et al., 2007. Interleukin 21 therapy increases the density of tumor infiltrating CD8+ T cells and inhibits the growth of syngeneic tumors. Cancer Immunol. Immunother., 56: 1417-1428. DOI: 10.1007/s00262-007-0285-4

156.Lamprecht, B., S. Kreher and I. Anagnostopoulos et al., 2008. Aberrant expression of the Th2 cytokine IL21 in Hodgkin lymphoma cells regulates STAT3 signaling and attracts Treg cells via regulation of MIP-3 alpha\}. Blood, 112: 3339-3347. http://edoc.mdc-berlin.de/9646/

157. Scheeren F.A., S.A. Diehl and L.A. Smit et al. IL21 is expressed in Hodgkin lymphoma and activates STAT5: Evidence that activated STAT5 is required for Hodgkin lymphomagenesis. Blood. 111: 4706-4715. http://www.pubmedcentral.nih.gov/articlerender.fc gi?artid=2343600
158. Menoret, E., S. Maiga and G. Descamps et al., 2008. IL-21 Stimulates human myeloma cell growth through an autocrine IGF-1 Loop. J. Immunol., 181: 6837-6842. http://www.ncbi.nlm.nih.gov/pubmed/18981102

159.Ettinger, R., S. Kluchen and P.E. Lipsky, 2008. Interleukin 21 as a target of intervention in autoimmune disease. Ann. Rheum. Dis., 67: 83-86. http://www.ncbi.nlm.nih.gov/pubmed/19022821 